\title{
R. 829
}

Technical Report

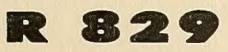

Sponsored by

NAVAL FACILITIES ENGINEERING COMMAND

December 1975

CIVIL ENGINEERING LABORATORY

Naval Construction Battalion Center

Port Hueneme, California 93043

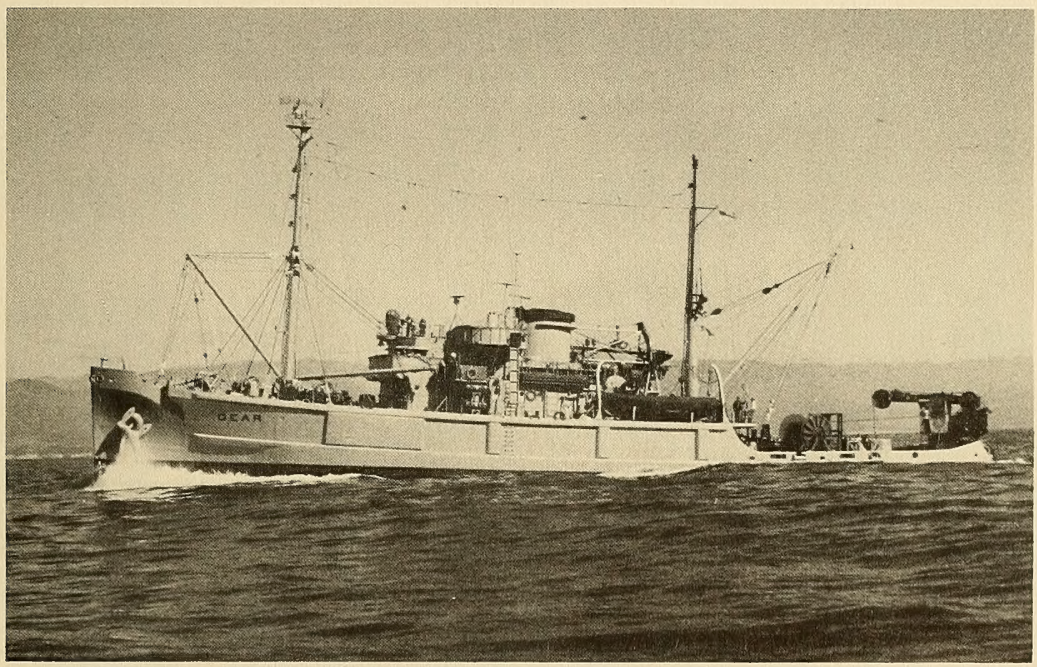

DEVELOPMENT AND EVALUATION OF A MOTION COMPENSATING LIFT SYSTEM FOR DEEP OCEAN CONSTRUCTION

by L. W. Hallanger, Ph D and R. L. Brackett

Approved for public release; distribution unlimited. 



\begin{tabular}{|c|c|c|}
\hline \multicolumn{2}{|r|}{ REPORT DOCUMENTATION PAGE } & $\begin{array}{c}\text { READ INSTRUCTIONS } \\
\text { BEFORE COMPLETING FORM }\end{array}$ \\
\hline & \begin{tabular}{l|l|} 
REPORT NUMEER & 2. GOVT ACCESSION NO. \\
TR-829 & DN044052 \\
\end{tabular} & 3. RECIPIENT'S CATALOG NUMBER \\
\hline \multirow{2}{*}{\multicolumn{2}{|c|}{$\begin{array}{l}\text { 4. TITLE (and Subtitle) } \\
\text { DEVELOPMENT AND EVALUATION OF A MOTION } \\
\text { COMPENSATING LIFT SYSTEM FOR DEEP OCEAN } \\
\text { CONSTRUCTION }\end{array}$}} & $\begin{array}{l}\text { 5. TYPE OF REPORT A PERIOD COVEREO } \\
\text { Final; Jul } 1969 \text { - Oct } 1974\end{array}$ \\
\hline & & 6. PERFORMING ORG. REPORT NUMBER \\
\hline \multicolumn{2}{|r|}{$\begin{array}{l}\text { 7. AUTHOR(s) } \\
\text { L. W. Hallanger, Ph D and R. L. Brackett }\end{array}$} & 8. CONTRACT OR GRANT NUMBER(S) \\
\hline \multicolumn{2}{|r|}{$\begin{array}{l}\text { 9. PERFORMING ORGANIZATION NAME AND ADDRESS } \\
\text { Civil Engineering Laboratory } \\
\text { Naval Construction Battalion Center } \\
\text { Port Hueneme, California } 93043\end{array}$} & $\begin{array}{l}\text { 10. PROGRAM ELEMENT, PROJECT, TASK } \\
\text { AREA \& WORK UNIT NUMBERS } \\
63713 \mathrm{~N}, \mathrm{~S} 46-36 \mathrm{X} \text {, WBS } 3.1410 \text {, } \\
3.1410 \mathrm{~A}\end{array}$ \\
\hline \multirow{2}{*}{\multicolumn{2}{|c|}{$\begin{array}{l}\text { 11. CONTROLLING OFFICE NAME AND ADDRESS } \\
\text { Naval Facilities Engineering Command } \\
\text { Alexandria, Virginia } 22332\end{array}$}} & $\begin{array}{l}\text { 12. REPORT DATE } \\
\text { December } 1975\end{array}$ \\
\hline & & $\begin{array}{l}\text { 13. NUMBER OF PAGES } \\
30\end{array}$ \\
\hline \multirow{2}{*}{\multicolumn{2}{|c|}{ 14. MONITORING AGENCY NAME \& ADDRESS(if dilferent from Controlling Office) }} & $\begin{array}{l}\text { 15. SECURITY CLASS. (of this report) } \\
\text { Unclassified }\end{array}$ \\
\hline & & $\begin{array}{l}\text { 15a. OECLASSIFICATION/DOWNGRADING } \\
\text { SCHEOULE }\end{array}$ \\
\hline \multicolumn{3}{|c|}{$\begin{array}{l}\text { 16. DISTRIBUTION STATEMENT rof this Report) } \\
\text { Approved for public release; distribution unlimited. }\end{array}$} \\
\hline \multicolumn{3}{|c|}{ 17. DISTRIBUTION STATEMENT (of the abstract entered in Block 20, if different from Report) } \\
\hline \multicolumn{3}{|c|}{ 18. SUPPLEMENTARY NOTES } \\
\hline \multicolumn{3}{|c|}{$\begin{array}{l}\text { 19. KEY WORDS (Continue on reverse side if necessary and identify by block number) } \\
\text { Lift systems, motion compensation, load handling, shipboard cranes. }\end{array}$} \\
\hline \multicolumn{3}{|c|}{$\begin{array}{l}\text { 20. ABSTRACT (Continue on teverse side if necessery and identify by block number) } \\
\text { A system to raise and lower loads in the deep ocean while providing lift-line tension } \\
\text { control and payload motion control was designed, fabricated, and tested. Design parameters } \\
\text { included a maximum wet payload weight of } 40,000 \text { pounds at a maximum operating depth } \\
\text { of } 6,000 \text { feet through sea conditions state } 4 \text { when the system is mounted on an ARS-type } \\
\text { vessel. A load-handling system of this type allows soft landing of a payload on the seafloor. } \\
\text { continued }\end{array}$} \\
\hline & EDITION OF 1 NOV 5515 OBSOLETE & Unclassified \\
\hline
\end{tabular}

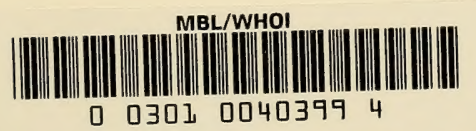




\section{Continued}

In addition, the reduction in the dynamic tensions in the lift line allows the use of smaller lines for a given payload weight, greater payload capacity for a specified line size, or a greater depth capability for a given line size. The concept selected for development called a "boom bobber" incorporated a boom pivoted at one end and supported by a relatively soft passive fluid spring. This spring decouples the payload from the motion of the support platform. At-sea testing included determination of system performance for two payloads of 12,000 and 40,000 pounds wet weight. Cable tensions and time-correlated motions of the ship, lift system, and payload were recorded. Data obtained were sufficient to prove the promise of the basic concept, even though both at-sea test series ended with specific component failures.

Library Card

Civil Engineering Laboratory

DEVELOPMENT AND EVALUATION OF A MOTION COMPENSATING LIFT SYSTEM FOR DEEP OCEAN CONST RUCTION (Final) by L. W. Hallanger, Ph D and R. L. Brackett TR-829 $30 \mathrm{p}$. illus

December 1975

Unclassified

1. Motion compensation

2. Load handling

I. 3.1410

A system to raise and lower loads in the deep ocean while providing lift-line tension control and payload motion control was designed, fabricated, and tested. Design parameters included a maximum wet payload weight of 40,000 pounds at a maximum operating depth of 6,000 feet through sea conditions state 4 when the system is mounted on an ARS-type vessel. A load-handling system of this type allows soft landing of a payload on the seafloor. In addition. the reduction in the dynamic tensions in the lift line allows the use of smaller lines for a given payload weight, greater payload capacity for a specified line size, or a greater depth capability for a given line size. The concept selected for development called a "boom bobber" incorporated a boom pivoted at one end and supported by a relatively soft passive fluid spring. This spring decouples the payload from the motion of the support platform. At-sea testing included determination of system performance for two payloads of 12,000 and 40,000 pounds wet weight. Cable tensions and time-correlated motions of the ship, lift system, and payload were recorded. Data obtained were sufficient to prove the promise of the basic concept, even though both at-sea test series ended with specific component failures.

$$
\text { SECURITY CLASSIFICATION OF THIS PAGE WhOM Nate Entered? }
$$


INTRODUCTION

Background . . . . . . . . . . . . . . . . . . . . . . . . . . . . . 1

Performance Objectives

CONCEPT SELECTION . . . . . . . . . . . . . . . . . . . . . . . . . . . . . . 1

Alternative Concepts . . . . . . . . . . . . . . . . . . . . . . 1

Evaluation . . . . . . . . . . . . . . . . . . . . . . . . . . 2

ANALYTICAL MODELS . . . . . . . . . . . . . . . . . . . . . . . . . . . . . 2

SYSTEM DESCRIPTION . . . . . . . . . . . . . . . . . . . . . . . . . . . . . . . 6

Motion-Compensating Equipment . . . . . . . . . . . . . . . . . . . . 6

Traction Unit . . . . . . . . . . . . . . . . . . . . . . . . . . . . . . . . . .

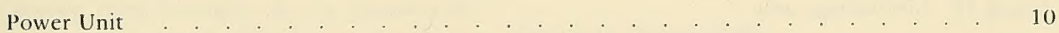

Turntable Unit . . . . . . . . . . . . . . . . . . . . . . 11

Line-Storage Unit . . . . . . . . . . . . . . . . . . . . . . . . 11

Control System . . . . . . . . . . . . . . . . . . . . . . . . 12

TEST PROGRAM . . . . . . . . . . . . . . . . . . . . . . . . 12

Shop Tests . . . . . . . . . . . . . . . . . . . . . . . . . . . . . . . . . . 12

Sea Tests . . . . . . . . . . . . . . . . . . . . . . . . . . . . . . . . . . . . . .

TEST RESULTS . . . . . . . . . . . . . . . . . . . . . . . . . . . . . 24

SUMMARY . . . . . . . . . . . . . . . . . . . . . . . . . . . . . . . 24

CONCLUSIONS AND RECOMMENDATIONS . . . . . . . . . . . . . . . . . . . . . . 25

APPENDIX -- TEST INSTRUMENTATION SYSTEM . . . . . . . . . . . . . . 27

\section{LIST OF ILLUSTRATIONS}

Figure 1. Single-degree-of-freedom model of MCLS . . . . . . . . . . . . . . . . 3

Figure 2. Response of simple MCLS system with zero damping . . . . . . . . . . . . . 4

Figure 3. Two-degree-of-freedom analytical model of MCLS . . . . . . . . . . . . . . 4

Figure 4. Two-degree-of-freedom analytical model of MCLS for computer use . . . . . . . 4 
Figure 5. Contractor's analytical model of MCLS

Figure 6. Response ratio for 40,000-pound load and 6,000-foot wire, showing effect of accumulator size

Figure 7. Response ratio for 40,000-pound load and 6,000-foot wire at 5\% rate, showing effect of load damping $\left(\mathbf{D}_{\mathbf{L}}\right)$

Figure 8. Response ratio for 6,000 -foot wire at $5 \%$ rate, showing effect of mass/weight ratio

Figure 9. Response ratio for 40,000-pound load and 6,000-foot length at 5\% rate, comparing nylon rope versus wire cable

Figure 10. Response ratio of nylon rope, showing effect of length

Figure 11. Force-to-amplitude ratio for 6,000-foot length of wire cable with 40,000-pound load, showing effect of accumulator size

Figure 12. Force-to-amplitude ratio for 6,000-foot length of nylon rope with 40,000-pound load, $5 \%$ accumulator size.

Figure 13. Motion-compensating lift system. Motion-compensating/traction unit (left); cable-storage reel (right)

Figure 14. Motion-compensating/traction unit

Figure 15. Line-storage unit .

Figure 16. Spring system schematic 15

Figure 17. Gas-transfer circuit

Figure 18. Boom-centering circuit .

Figure 19. MCLS control console

Figure 20. $M V$ Gear

Figure 21. MCLS installed on $M V$ Gear

Figure 22. Light test payload

Figure 23. Heavy test payload

Figure 24. Shipboard instrumentation

Figure 25. Payload-mounted instrumentation

Figure 26. Flow chart for instrumentation system

\section{LIST OF TABLES}

Table 1. Performance Requirements of Motion-Compensating Lift System 


\section{INTRODUCTION}

\section{Background}

Handling heavy loads in the ocean is usually restricted by ship-motion-induced dynamic line loads that can be many times the magnitude of the static load. The manner in which the restrictions limit the load-handling operations is governed by the weather, ship, payload, and line characteristics. Many attempts have been made in recent years to develop a system that would compensate for ship motion and thus reduce the dynamic forces in the cables. Such compensation would provide a higher reliability and a greater safety factor in load-handling operations. Notable among these attempts are the passive ramtensioner system designed for the Navy's Large Object Salvage System* ${ }^{*}[1]$ and the numerous activetype "constant-tension" oceanographic winches.

\section{Performance Objectives}

With the Navy's increasing interest in placing heavy loads on the ocean floor a system is needed that is capable of lowering or raising multiton loads in the ocean with a minimum of restrictions imposed by weather-caused ship motions. This requirement is included in the Deep Ocean Technology Technical Development Plan (DOT TDP)**. The performance characteristics defined by the DOT TDP are: (1) depth capability of 6,000 feet; (2) load capacity between 20 and 100 tons; (3) lowering or lifting rate of 1 to $2 \mathrm{ft} / \mathrm{sec}$; (4) maximum dynamic stress in the lift cable of 10 to $30 \%$ of static stress; (5) maximum vertical oscillation of the load of 1 to 3 feet with respect to the bottom, and (6) an operational capability in sea state 3 .
The Naval Facilities Engineering Command (NAVFAC) assigned the development of the desired lifting system to the Civil Engineering Laboratory (CEL). A complete set of performance specifications (listed in Table 1) was developed based on the DOT TDP, the current state-of-the-art, and predictions of how far the technology could reasonably be advanced in one step. The ship motion limits were obtained from operating records obtained during previous CEL work aboard ATF and ARS vessels. In addition to the requirements of Table 1 , it was specified that the system be self-contained, physically compact, suitable for use aboard vessels such as the ATF, ARS, ASR, and capable of utilizing wire and synthetic lift lines.

\section{CONCEPT SELECTION}

\section{Alternative Concepts}

Five different concepts were evaluated and judged on their potential ability to meet the performance objectives (Table 1). Of these, four were of the active, feedback, servo-controlled type, and one was a passive, nonfeedback system. Two of the active systems used the line-storage drum as the main traction and compensating unit, and two utilized a driven traveling block to provide some of the required compensation capability.

Of the single-drum concepts one was to use a diesel-hydraulic system to drive a hydraulic drive motor. The other was to be driven directly by a diesel power source connected through a constantly slipping servo-controlled clutch.

One of the traveling-block concepts included a hydraulically driven traction/line-storage unit combined with a servo-controlled hydraulically driven

\footnotetext{
* Hydronautics, Inc. TR-613-1: Large object salvage system (LOSS) feasibility and analytical studies, by E. R. Miller, Jr. Laurel, MD, Dec 1966.

** Classified reference. (Reference citation available from Civil Engineering Laboratory, Naval Construction Battalion Center, Port Hueneme, California 93043, to qualified requestors with need to know.)
} 
Table 1. Performance Requirements of

Motion-Compensating Lift System

\begin{tabular}{|c|c|}
\hline Item & Operational Requirements \\
\hline Payload capacity & $40,000 \mathrm{lb}$ wet weight \\
\hline Operating depth & $6,000 \mathrm{ft}$ \\
\hline Lift rate & $1 \mathrm{ft} / \mathrm{sec}$ \\
\hline $\begin{array}{l}\text { Dynamic line } \\
\text { tension }\end{array}$ & $< \pm 10 \%$ of static load \\
\hline Load motion & $< \pm 0.5 \mathrm{ft}$ with respect to the bottom \\
\hline Lift line & Wire ropes up to $1-1 / 2$ in. in diameter \\
\hline $\begin{array}{l}\text { Ship limits motion } \\
\text { (maximum) }\end{array}$ & \\
\hline Displacement & $\pm 9 \mathrm{ft}$ \\
\hline Velocity & $\pm 7 \mathrm{ft} / \mathrm{sec}$ \\
\hline Acceleration & $\pm 8 \mathrm{ft} / \mathrm{sec}^{2}$ \\
\hline
\end{tabular}

ram tensioner to control the traveling block. The other concept utilized slipping servo-controlled clutches to control both the line-storage/traction unit and the traveling block.

The passive concept, also called a "boombobber" system, was based on the use of a soft spring to support the load through a pivoted boom. Operating at ship input frequencies significantly greater than boom-spring resonance would decouple ship motion from the payload, to give the desired tension and motion control.

\section{Evaluation}

In the evaluation of the technical desirability of each concept, a number of points were considered: (1) the question of whether the conceptual system could meet the performance objectives, (2) the estimated overall performance capability, (3) the potential reliability of the system, and (4) the physical characteristics such as size, weight, and component arrangement.

The four dynamic-system concepts had much in common, including a power unit of about $1,200 \mathrm{hp}$ to provide the motion-compensation capability, an active, servo feedback control system and associated controls, and significant lift-line travel over sheaves while compensating for support-platform motions.
The probability of successfully meeting the performance objectives varied considerably among these four concepts; those based on a constantly slipping, servo-controlled clutch drive system were preferred because of the extremely fast response offered by this approach. The hydraulic drive systems utilized in the other two active concepts are inherently slower in responding to control signals and thus provide poorer dynamic control of line tension and payload motion.

The fifth concept, a passive boom-bobber system, had the following advantages:

1. Simpler in design and more compact than the active system

2. Suspension of the payload and lift wire on a soft fluid spring, resulting in a significantly longer natural resonant period for the spring than for the ship-motion periods and effectively decoupling the payload motion from support-platform motion

3. Almost no lift-line travel over sheaves while compensating for support-platform motion, resulting in considerable reduction of fatigue wear of the lift line

4. Holding of the payload at any depth without requiring power from the system

5. Maximum power required for payload lifting operation estimated at $200 \mathrm{hp}$

\section{Relatively small size of hardware}

In addition to these factors, a Navy-wide evaluation team judged that the probability of the concept's being successfully built was high and the performance objectives could be met with such a system. Therefore, the passive design concept was selected for development.

\section{ANALYTICAL MODELS}

During the design process both the contractor and CEL developed analytical models to predict system performance. The models are similar in that they are linear and use lumped parameters.

The first CEL model, shown schematically in Figure 1, ignored parameters such as lift-line elasticity, system friction, ${ }^{*}$ and payload drag. These parameters were recognized as important but, because

* Including breakaway friction, or "sticktion." 


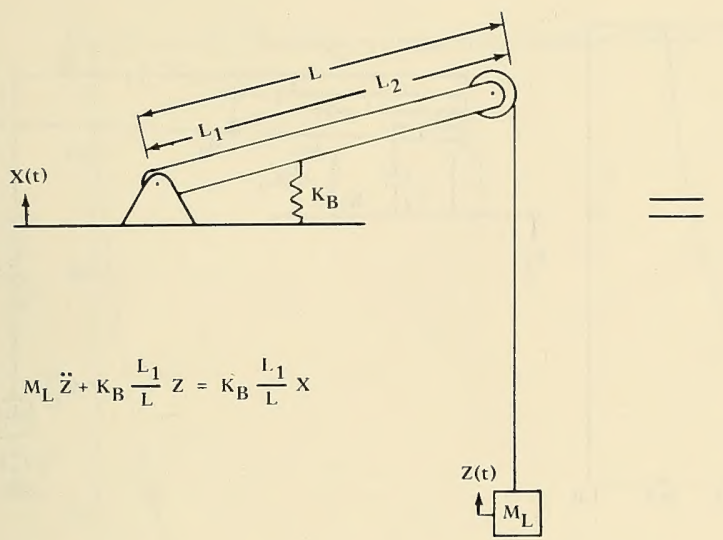

(a)

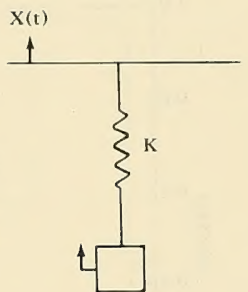

$M \ddot{z}+K Z=K X$

where $M=M_{L}$

$\mathrm{K}=\mathrm{K}_{\mathrm{B}} \mathrm{L}_{1} / \mathrm{L}$

Figure 1. Single-degree- of-freedom model of MCLS.

of the uncertainty of the coefficients at the time the model was developed, they were omitted; this model was intended to produce only gross approximations. Physically, the MCLS (Motion Compensating Lift System) is arranged as shown in Figure 1a with the boom, pivoted at one end, supported by the spring $\mathbf{K}_{\mathbf{B}}$ at a distance $\mathbf{L}_{\mathbf{1}}$ from the pivot point. The boom supports a payload $\mathbf{M}_{\mathbf{L}}$ on a rigid cable suspended from the outer end at a distance $\mathbf{L}$ from the pivot point. Motion of the support platform is represented by $\mathbf{X}(\mathrm{t})$ and motion of the payload by $\mathbf{Z}(\mathrm{t})$. This model is mathematically equivalent to the simple spring/mass system of Figure $1 \mathrm{~b}$ in which the input motion is $\mathbf{X}(\mathbf{t})$ and the response $\mathbf{Z}(\mathbf{t})$. The ratio of the amplitude of the load motion $\mathbf{Z}(\mathbf{t})$ to the input motion $\mathbf{X}(\mathrm{t})$ (that is, the response of this system) is shown in Figure 2 as a function of the period of the input $\tau$ divided by the resonance period $\tau_{\mathbf{n}}$. Damping, or drag, forces present at the payload tend to decrease system response while damping in the compensator mechanism tends to increase system response by increasing the magnitude of the forces acting on the lift line at the boom tip.
Later models used by CEL included those shown in Figures 3 and 4, with the latter being programmed for computer-based analysis. The criteria used in the design of the MCLS included minimizing internal friction and damping in the compensator unit and keeping the system's resonant period $\tau_{\mathbf{n}}$ significantly larger than the expected periods of the input $\mathbf{X}(\mathbf{t})$. These criteria tend to reduce system response, and thus to improve system performance. With the system designed so that the value of $\mathbf{K}$ is small, the dynamic line-tension variations are kept within the desired limits (Table 1).

The contractor's analytical model (Figure 5) is similar to CEL's bur incorporates damping factors in the spring system and at the payload and also includes the mass and elasticity of the cable in a simple, two-segment, lumped-mass approximation. A mathematical description of this system was developed with this model, resulting in the four simultaneous second-order differential equations below

$$
\mathrm{M}_{\mathrm{C}} \ddot{\mathrm{Z}}_{3}+\mathrm{D}_{\mathrm{C}} \dot{\mathrm{Z}}_{3}+\frac{3}{2} \mathrm{~K}_{\mathrm{C}} \mathrm{Z}_{3}=\mathrm{K}_{\mathrm{C}}\left(\mathrm{X}+\mathrm{Y}+\frac{\mathrm{Z}_{2}}{2}\right)
$$




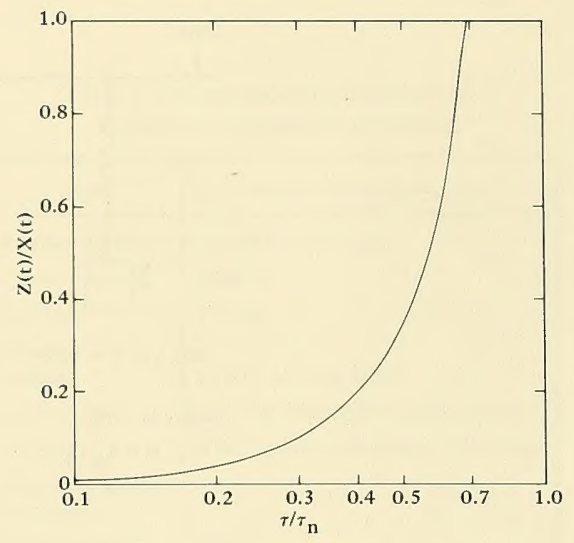

Figure 2. Response of simple MCLS system with zero damping.

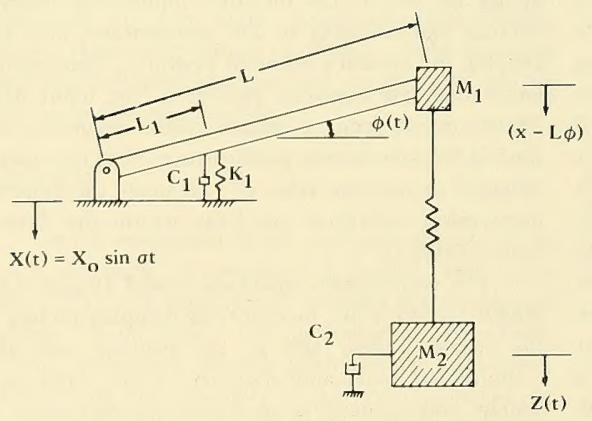

Figure 4. Two-degree-of-freedom analytical model of MCLS for computer use.

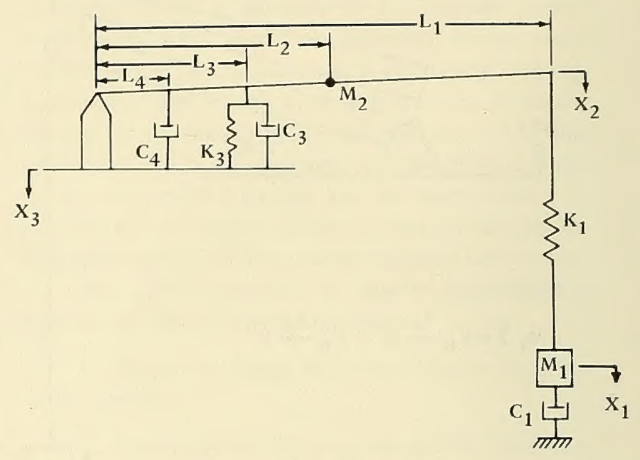

Figure 3. Two-degree-of-freedom analytical model of MCLS.

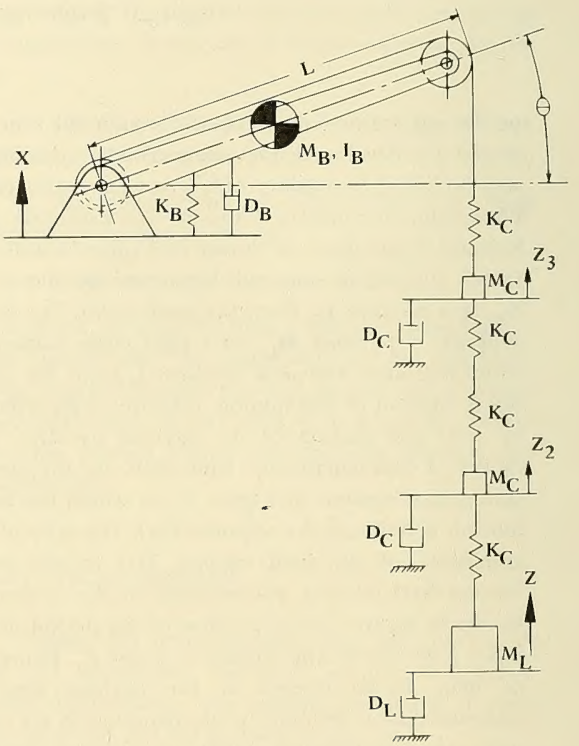

Figure 5. Contractor's analytical model of MCLS. 


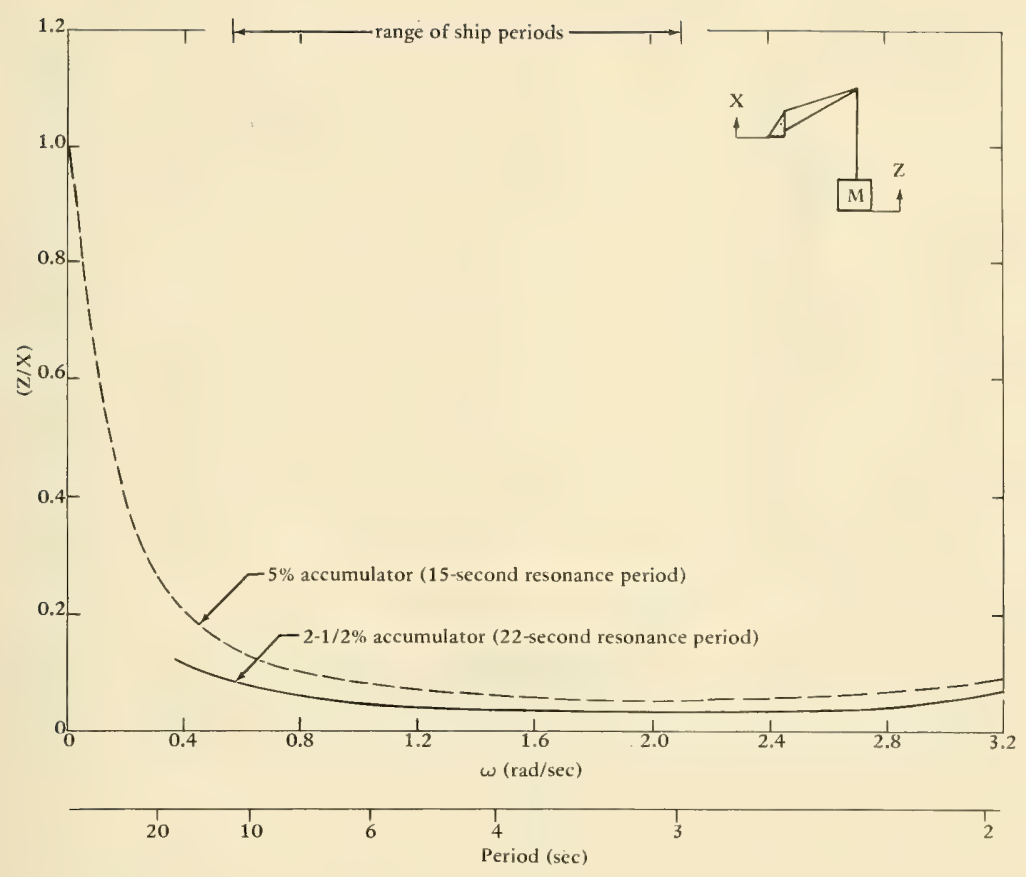

Figure 6. Response ratio for 40,000-pound load and 6,000-foot wire, showing effect of accumulator size.

$$
\begin{gathered}
M_{C} \ddot{z}_{2}+D_{C} \dot{z}_{2}+\frac{3}{2} K_{C} Z_{2}=K_{C}\left(\frac{z_{3}}{2}+z\right) \\
M_{L} \ddot{z}+D_{L} \dot{z}+K_{C} Z=K_{C} Z_{2} \\
M_{y} \ddot{Y}+D_{y} \dot{Y}+K_{y} Y=-M_{x} \ddot{x}-K_{C}\left(X-z_{3}\right)
\end{gathered}
$$

where $\mathbf{Y}=\mathbf{L} \sin \theta$

$$
\begin{aligned}
\mathbf{M}_{\mathbf{y}}= & \text { a function of the boom mass and } \\
& \text { angular inertia } \\
\mathbf{D}_{\mathbf{y}}= & \text { a function of the spring drag force } \\
& \text { and spring-boom geometry } \\
\mathbf{K}_{\mathbf{y}}= & \text { a function of the spring constant and } \\
& \text { spring-boom geometry }
\end{aligned}
$$
$\begin{aligned} M_{\mathbf{x}}= & \text { a function of the boom mass and its } \\ & \text { position along the boom length }\end{aligned}$

and where the boom-tip dynamic load $\left(\mathbf{F}_{\mathbf{L}}\right)$ is given by

$$
F_{L}=K_{C}\left(X+Y-Z_{3}\right)
$$

A computer analysis of these equations based on a Laplace transform allowed prediction of the system transfer function $\mathbf{Z} / \mathbf{X}$ and dynamic line tension as functions of the frequency (or period) of the support-platform motion $\mathbf{X}(\mathrm{t})$, type and length of lift line, spring accumulator size, and payload massweight ratio as shown in Figures 6 through 12. 


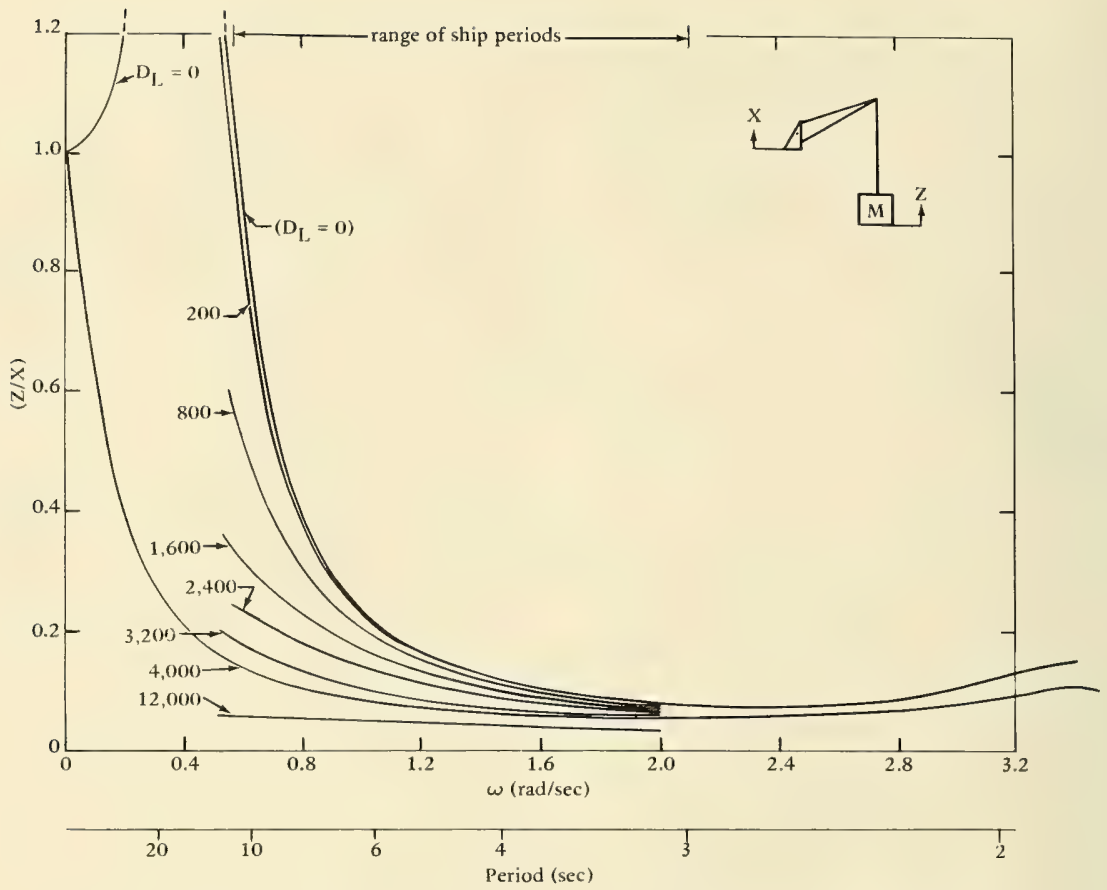

Figure 7. Response ratio for 40,000-pound load and 6,000-foot wire at $5 \%$ rate, showing effect of load damping $\left(\mathbf{D}_{\mathbf{L}}\right)$.

\section{SYSTEM DESCRIPTION}

The MCLS is a passive system designed to decouple ship motion from the payload. This decoupling is accomplished by support of the load on a spring whose resonant frequency is significantly lower than the ship-motion frequencies that will be encountered. The system consists of five functional components: (1) the motion-compensation assembly, designed to decouple the payload from ship motion; (2) the traction unit to pay out and haul in the load line; (3) the diesel-hydraulic power source to provide all the power for system operation; (4) the operatorcontrol section; and (5) the takeup or cable-storage reel to store the unused portion of the load-support cable.
These five components of the complete MCLS are contained in two separate units. The motioncompensating/traction unit (left in Figure 13) includes the passive compensation assembly, the traction winch, the diesel-hydraulic power source, and the operator controls for the system. The cablestorage reel is separate and is shown on the right in Figure 13. Additional details of these two units are shown in Figures 14 and 15.

\section{Motion-Compensating Equipment}

The boom of the motion-compensating equipment is pivoted at one end, has the payload lift line suspended from the other end, and is supported 


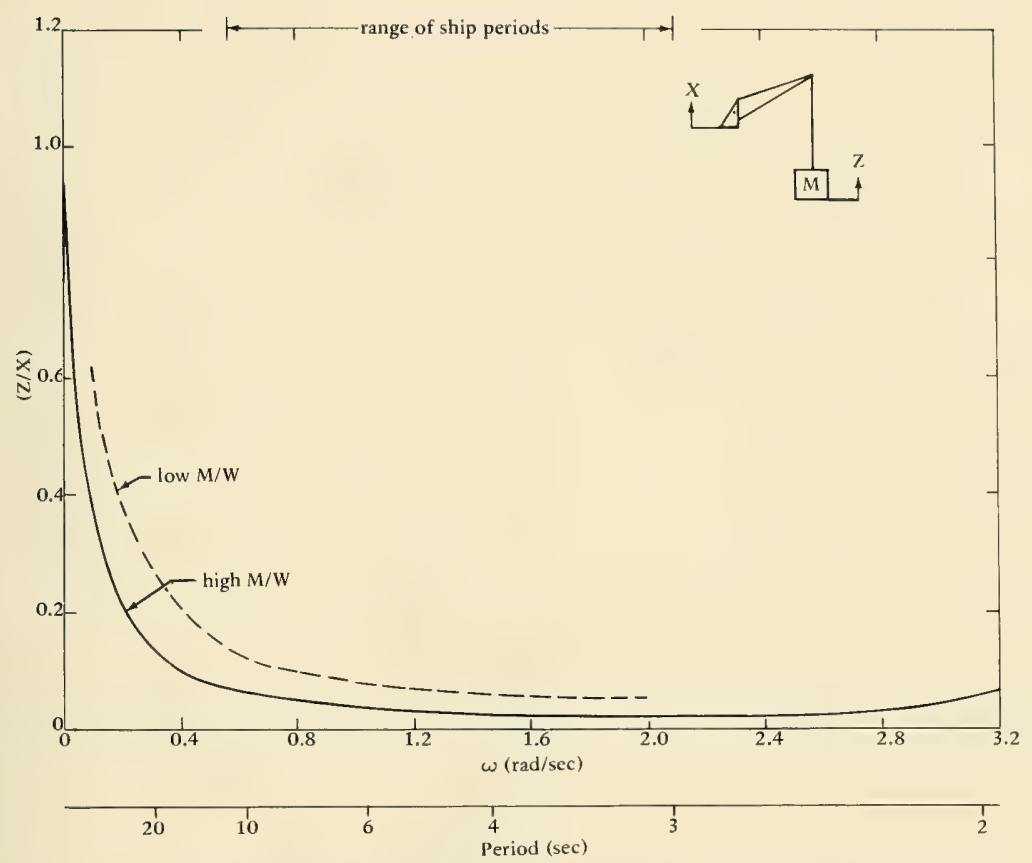

Figure 8. Response ratio for 6,000-foot wire at $5 \%$ rate, showing effect of mass/weight ratio.

by a pneumatic spring cylinder. A pair of hydraulic cylinders are used to control the boom position when operating in a "hard" (noncompensated) mode. With the hydraulic cylinders in operation, the system is capable of lifting loads in the same manner as with a conventional crane. During operation in the compensating mode the hydraulic cylinders are shortcircuited and, thus, effectively removed from system operation.

The pneumatic spring is the central component of the compensating system, and its characteristics determine how well the system operates. Figure 16 shows a simplified spring circuit. A pneumatic cylinder is used to directly support the boom, payload, and lift line. To obtain the required, relatively small, pressure changes over the boom stroke, additional gas volume is provided from eight separate high-pressure gas bottles that can be connected together in a variety of ways using the manual crossconnect valves (12C through $\mathrm{H}$ in Figure 16).

Accumulator volume is also varied during operation as a function of boom position to increase the spring constant as the boom approaches the lower limits of its travel range. To accomplish this, a mechanical scotch yoke arrangement is activated by pins attached to the boom. Three separate yokes are used to control valves $12 \mathrm{~A}$ and $\mathrm{B}$ and 23 , allowing the accumulator volume to be reduced in three incremental steps. Valve 23 is the last of the three to be activated and completely separates the spring 


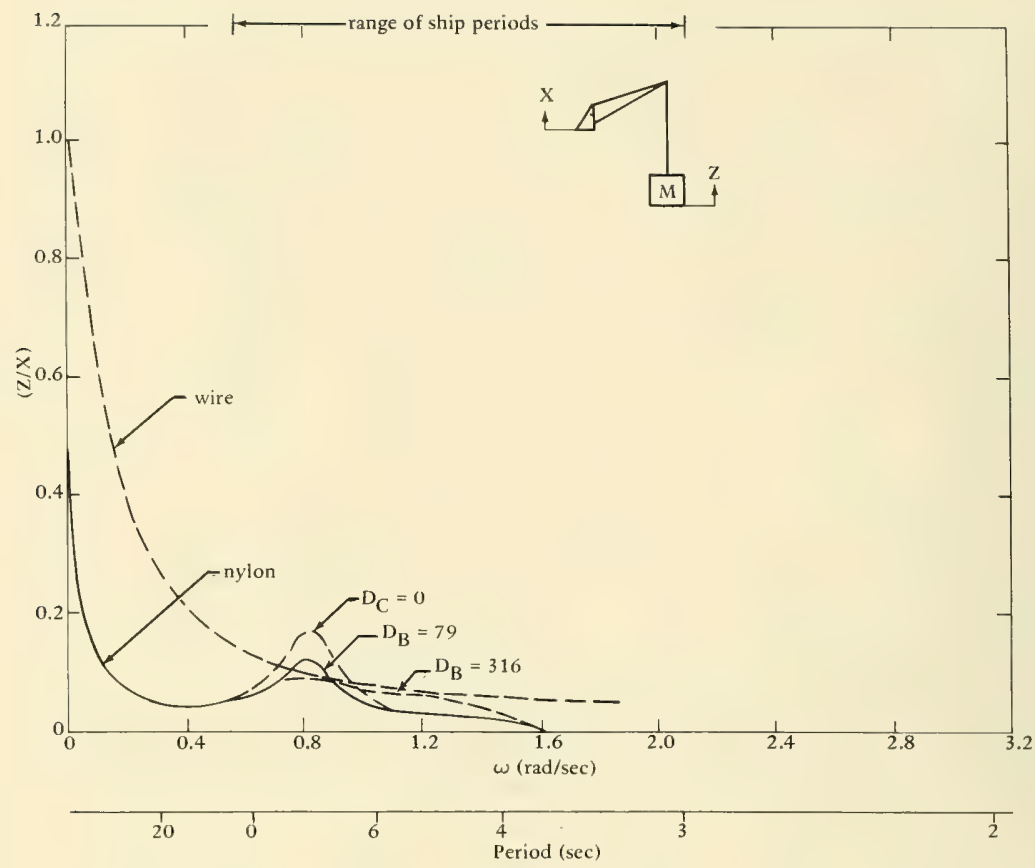

Figure 9. Response ratio for 40,000-pound load and 6,000-foot length at 5\% rate, comparing nylon rope versus wire cable.

cylinder from the external accumulator volume. Pin position (adjustable only when the system is in the hard mode) and the settings of the manual crossover valves govern the specific shape of the dynamic spring characteristic as a function of boom position. Nitrogen gas is used in this system to avoid the potential problems associated with ignition of oils when exposed to high-pressure air.

Changes in the static boom-tip load are compensated for by adding or removing gas from the spring system until the mean gas pressure just balances the load at the midpoint position of boom travel. The gas is transferred by means of the gas-transfer circuit shown in Figure 17. Activation of valves $19 \mathrm{~A}$ and $\mathrm{C}$ allows the compressor to pump nitrogen from the storage bank into the spring and, thus, to increase spring pressure to adjust for an increased boom-tip load. Activation of valves $19 \mathrm{~B}$ and $\mathrm{D}$ allows gas to be transferred back into the storage bank. Control of this function may be either automatic or manual.

Valves $19 \mathrm{~A}$ through $\mathrm{D}$ are pilot-activated by the circuit shown in Figure 18. This circuit is basically a mechanical integrator that senses by means of valve 65 whether the boom position is above or below its midpoint.

The two banks of hydraulic accumulators, $63 \mathrm{~A}$ through $\mathrm{C}$ and $63 \mathrm{D}$ through $\mathrm{F}$, and the associated bleed-off valves $64 \mathrm{~A}$ through $\mathrm{C}$ are used to provide the desired averaging function in the following 


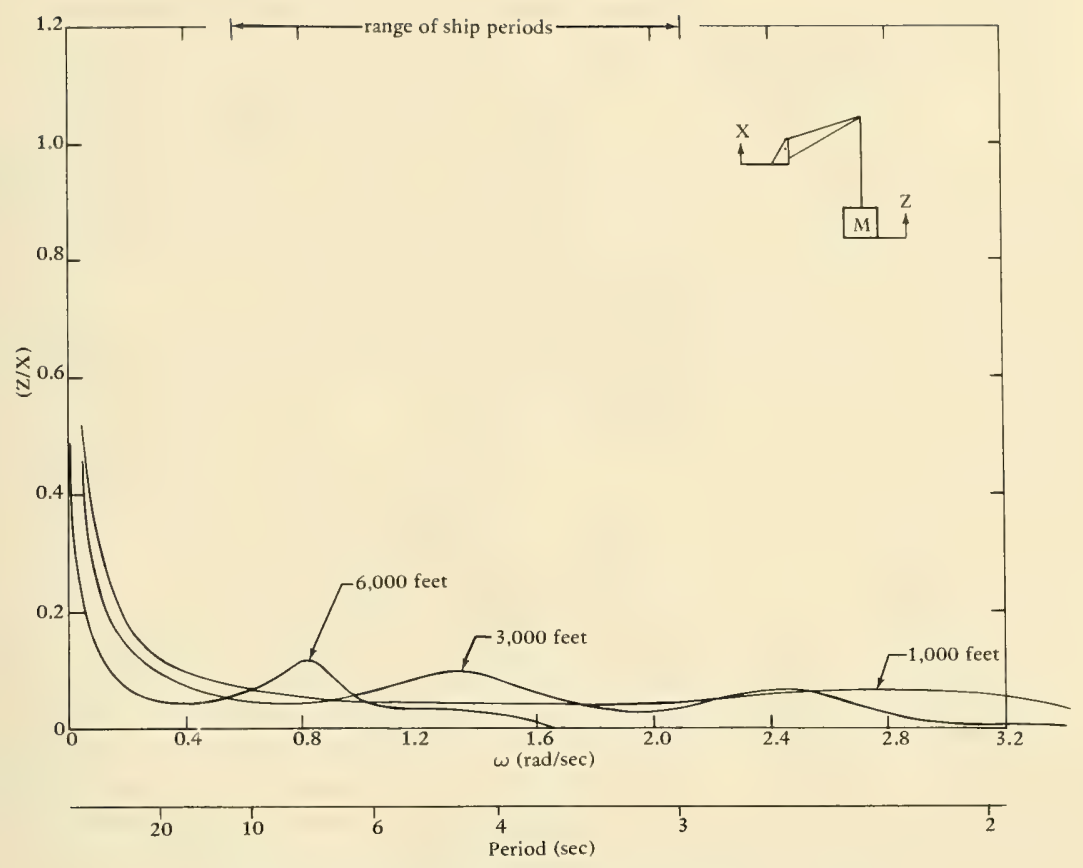

Figure 10. Response ratio of nylon rope, showing effect of length.

manner. In the automatic mode, valve $60 \mathrm{~A}$ is in the center (off) position, and valve $60 \mathrm{~B}$ is in the automatic position (as shown). Oil is supplied to the circuit from the hydraulic source via the pressure regulator $67 \mathrm{~A}$ and the pressure-compensated flowcontrol valve 66 . With the boom tip above midpoint, valve 65 supplies oil to accumulator bank $63 \mathrm{D}$ through $\mathrm{F}$ while simultaneously releasing oil from accumulator bank $63 \mathrm{~A}$ through $\mathrm{C}$ through flowcontrol valve 64 and back to the main reservoir. When the boom position moves to below the midpoint, the oil supply is shifted to $63 \mathrm{~A}$ through $\mathrm{C}$ while $63 \mathrm{D}$ through $\mathrm{F}$ are connected to the drain. If the average boom position is at the midpoint, the pressures in the two accumulator banks remain equal. If, however, the average boom position should move away from midpoint, one accumulator bank would receive more oil and, thus, have a higher pressure than the other. When the required pressure difference is reached, valve 61 is activated, turning on both the appropriate gas-transfer valves $19 \mathrm{~A}$ through $\mathrm{D}$ and the compressor, to transfer gas in the direction necessary to bring the average boom position back to midpoint. Control-system response time is governed by both the relative and absolute settings of valves $64 \mathrm{~A}$ through 66 , and pressure regulator $67 \mathrm{~A}$. For manual control, valve $60 \mathrm{~A}$ bypasses the boom-controlled valve and the flow-control valves $64 \mathrm{C}$ and 66 . A boom-velocity 


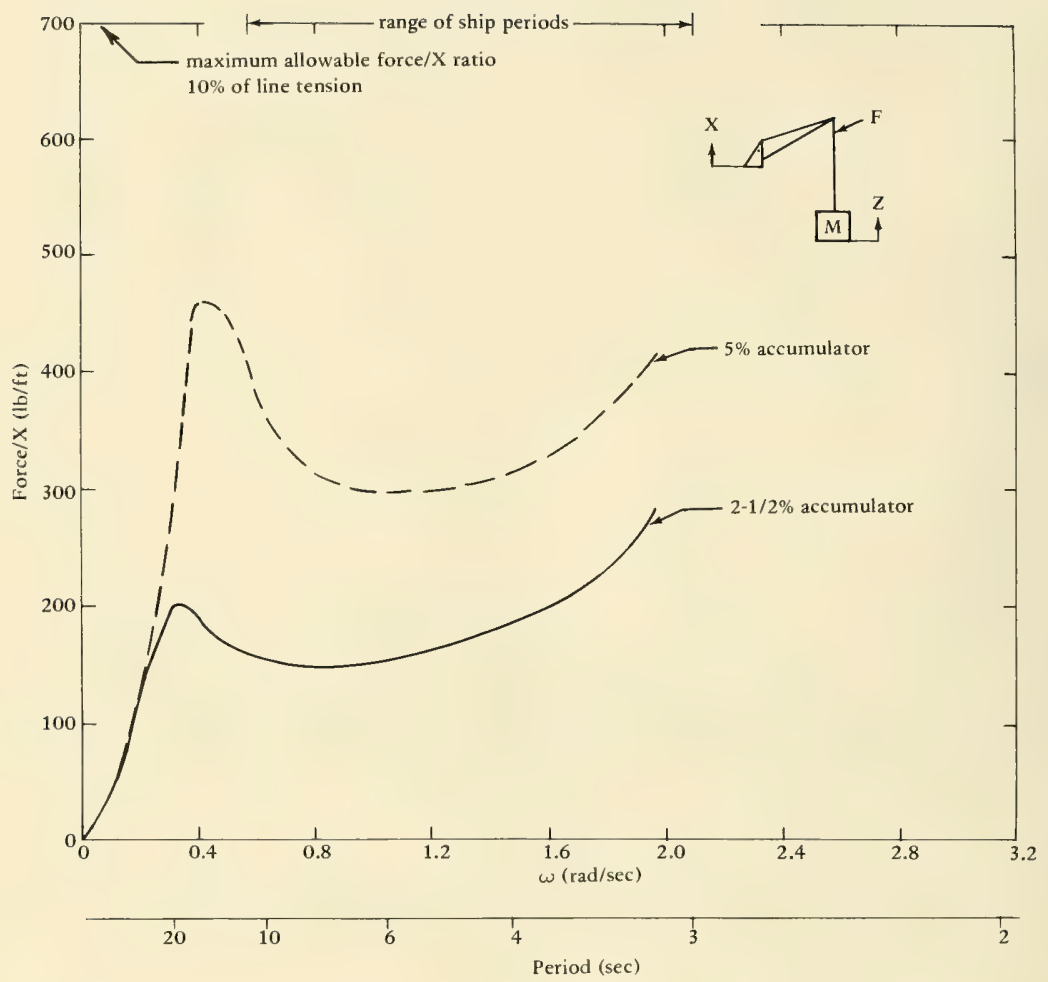

Figure 11. Force-to-amplitude ratio for 6,000-foot length of wire cable with 40,000-pound load, showing effect of accumulator size.

feedback system, also shown in Figure 18, is incorporated to improve the performance of the automatic-centering system by adjusting the position of the cam that operates the boom-position sensor (valve 65 ) as a function of boom-tip speed.

\section{Traction Unit}

The traction winch, shown in Figure 14, is of the conventional double-drum, inclined-axis type, using six wraps of line around the drums. Drum liners are interchangeable to allow the use of different types and sizes of line. The drive is by a low-torque, highspeed, hydraulic motor through a reduction gear box and then through a single pinion gear that drives the bull gears on both drums. Designed maximum speed of the line is $60 \mathrm{ft} / \mathrm{min}$ at a maximum line pull of 65,000 pounds. The hydraulic circuitry is arranged so that the winch motor can be used as a pump, the main pump as a motor, and the diesel engine with its Jacobs compression brake as an energy-absorbing device (air compressor) to provide controllable dynamic braking during lowering operations. A spring-set, hydraulically released brake designed to stop a runaway load is also incorporated into the unit.

\section{Power Unit}

The diesel-hydraulic power unit is driven by a 743-cubic-inch-displacement, turbocharged Cummins 


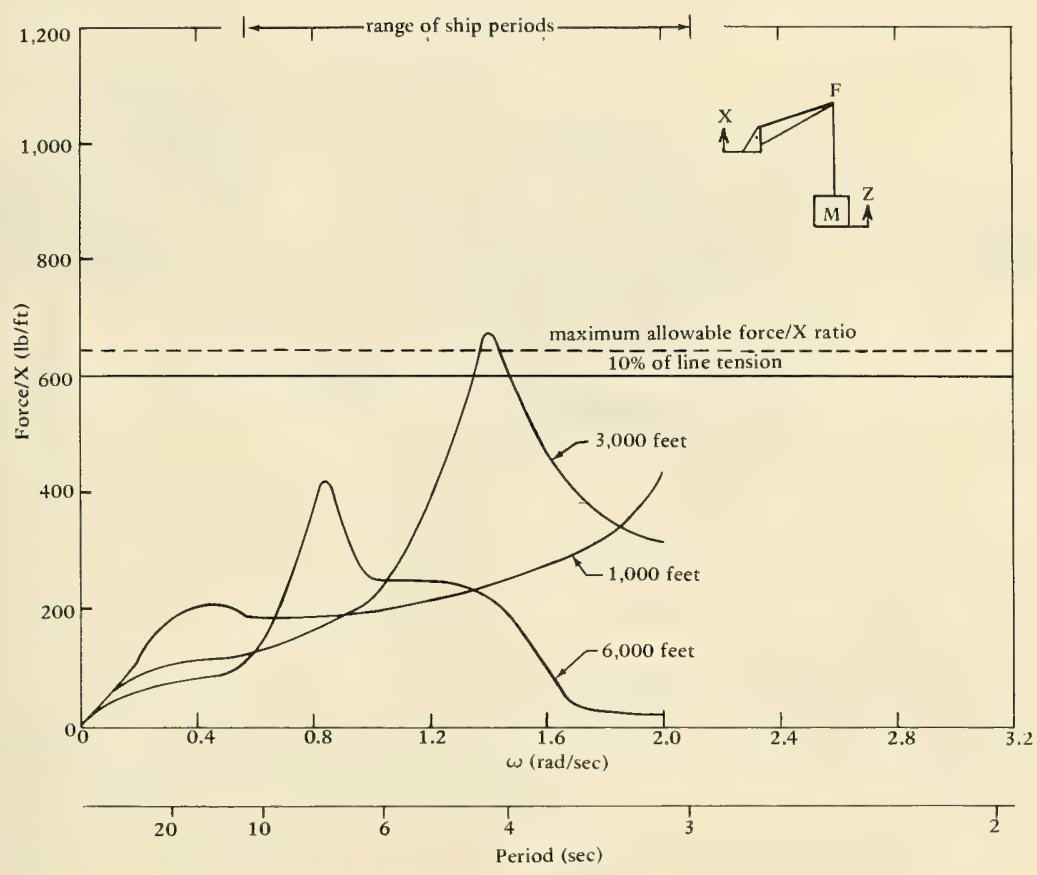

Figure 12. Force-to-amplitude ratio for 6,000 -foot length of nylon rope with 40,000-pound load, $5 \%$ accumulator size.

diesel, rated at $250 \mathrm{bhp}$ at $2,100 \mathrm{rpm}$, which drives both a main hydraulic pump that powers the traction winch and auxiliary pumps that drive the other system components. The engine is fitted with a Jacobs compression brake which, when activated, converts the engine into a compressor capable of absorbing almost as much power as the normal output rating. When the unit operates in this mode, auxiliary hydraulic pumps continue to be driven and all system functions remain operable.

\section{Turntable Unit}

The motion-compensating, traction, and power components are all mounted on a turntable capable of 360-degree rotation controlled by the operator to allow offloading or onloading from the support-vessel deck. The turntable also permits the placing of the boom tip at the most advantageous position with respect to the ship for a lifting or lowering operation.

\section{Line-Storage Unit}

The line-storage unit is shown to the right in Figure 13 and in detail in Figure 15. It is capable of storing 7,000 feet of 3 -inch-diameter nylon line (volume limit) or 7,000 feet of 1-1/2-inch-diameter wire rope (weight limit). Line tension during haul-in or payout is selected by the operator and automatically controlled to a level between 0 and 2,000 


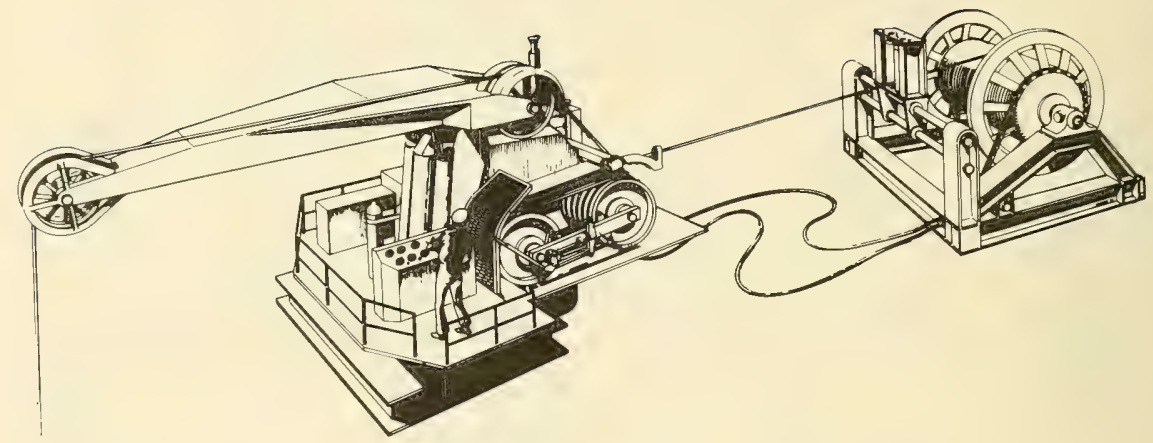

Figure 13. Motion-compensating lift system. Motion-compensating/traction unit (left); cable-storage reel (right).

pounds; normal setting for wire rope is about 500 pounds. The level-wind mechanism is adjustable for all line diameters between $1 / 2$ and 3 inches. Provision was made for the addition of electrical slip rings to allow the future use of electromechanical cables.

\section{Control System}

Operation of the MCLS is controlled from a single point by one operator. The controls and instruments, shown in Figure 19, are grouped in functional clusters for ease of operation. The control console itself is constructed in an L-shape with the top sloping down toward the operator.

A typical operation begins with the system in the hard mode and the engine running. After completion of a preoperation checklist the operator raises the payload off the deck high enough to clear the ship's rail. Then he activates the turntable control to rotate the payload out over the stern into launch position. When the launch position is reached he begins to payout cable and, as soon as the payload is in the water, he shifts into soft mode and activates the automatic boom-centering circuit (spring pressure was set previously to just balance the load). Rate of descent is then controlled by the winch control lever and, with the system operating as designed, this is the only control the operator needs to touch during the remainder of the lowering or lifting operation. Recovery is accomplished by reversing the launch procedure.

\section{TEST PROGRAM}

\section{Shop Tests}

Formal testing of the MCLS began at the contractor's facility with a static load test soon after fabrication of the hardware. Strain gages were placed at all critical areas, and a series of loads was applied to the boom tip. Analysis of the strain-gage information showed one location near the turntable bearing mount where stress levels would be marginal at the designed maximum boom-tip load. The addition of stiffening gussets eliminated the high stress levels.

Dynamic shop tests were made to determine the system's natural resonant period. In these tests the boom in the compensated mode was displaced from its mean position and released. Recording of boom displacement as a function of time allowed determination of the natural period for various boom-tip loads. Several tests were made for each of four loads with the following results:

\begin{tabular}{cc}
$\begin{array}{c}\text { Boom-Tip Load } \\
\text { (lb) }\end{array}$ & $\begin{array}{c}\text { Average Resonant Period } \\
\text { (sec) }\end{array}$ \\
\hline 10,180 & $\frac{13.8}{19,240}$ \\
44,000 & 13.3 \\
62,350 & 11.6 \\
& 9.8
\end{tabular}

It was also determined-from the shape of the response curves - that the internal system damping was between 30 and $100 \%$ of the critical point, the percentage decreasing with increasing payload weight. 


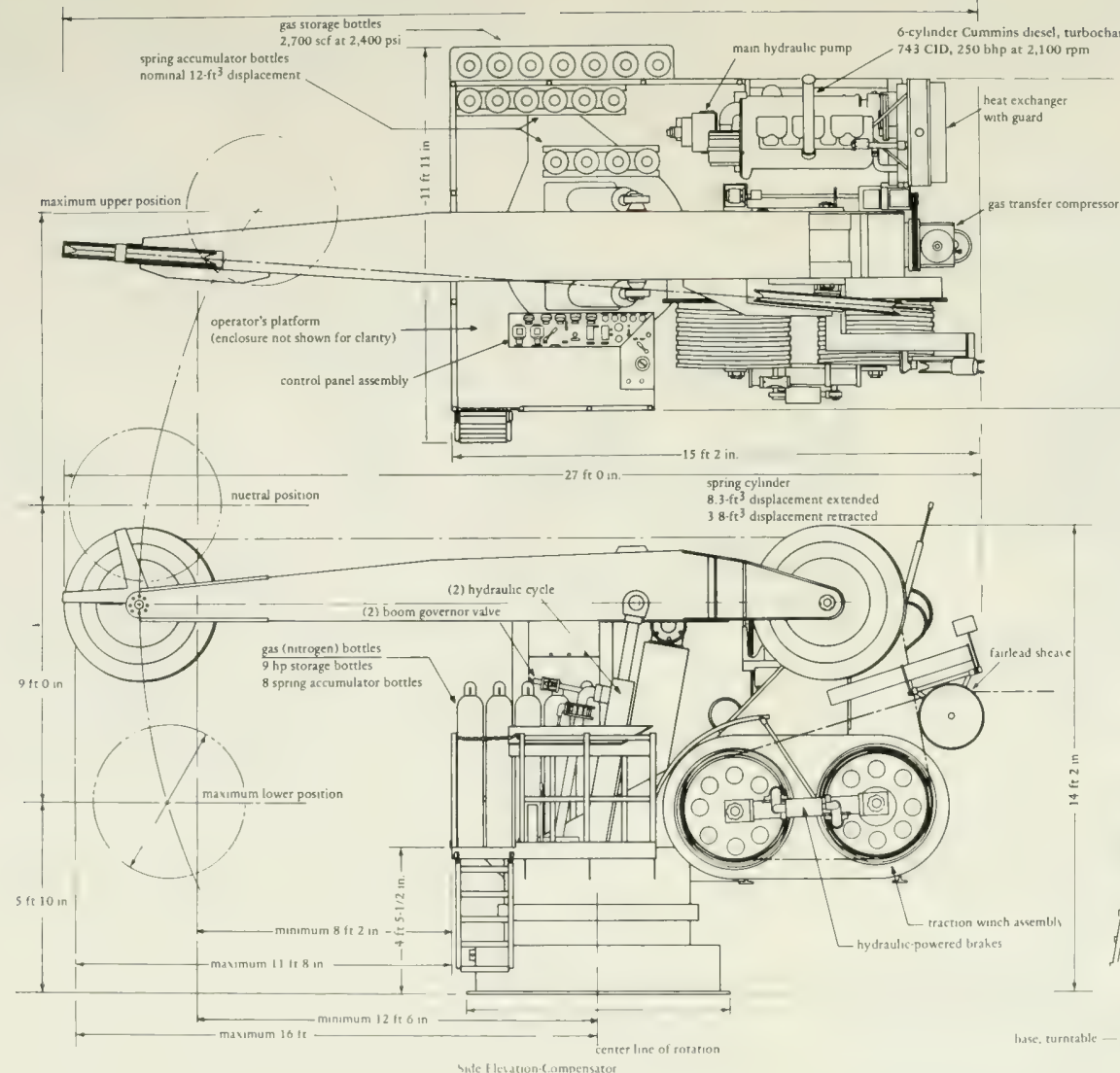

Figure 14. Motion-compensating/traction untt. 

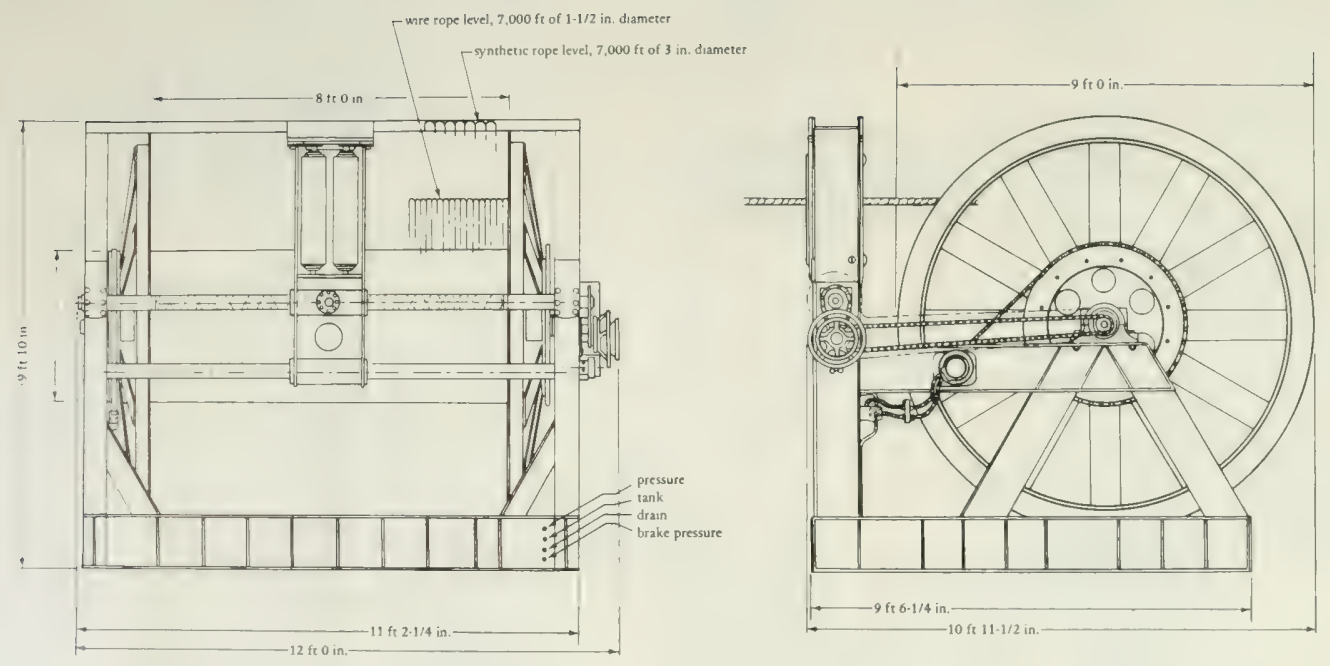

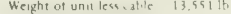
Weight of 7,050 fect of $1-1 / 2$ cable $-27,509$ lts . Weight of unit and cable $-41,06010$ Designed line pull $-2,00016$ Reel-in speed $-60 \mathrm{fumin}$

Figure 15. Line-storage unst. 


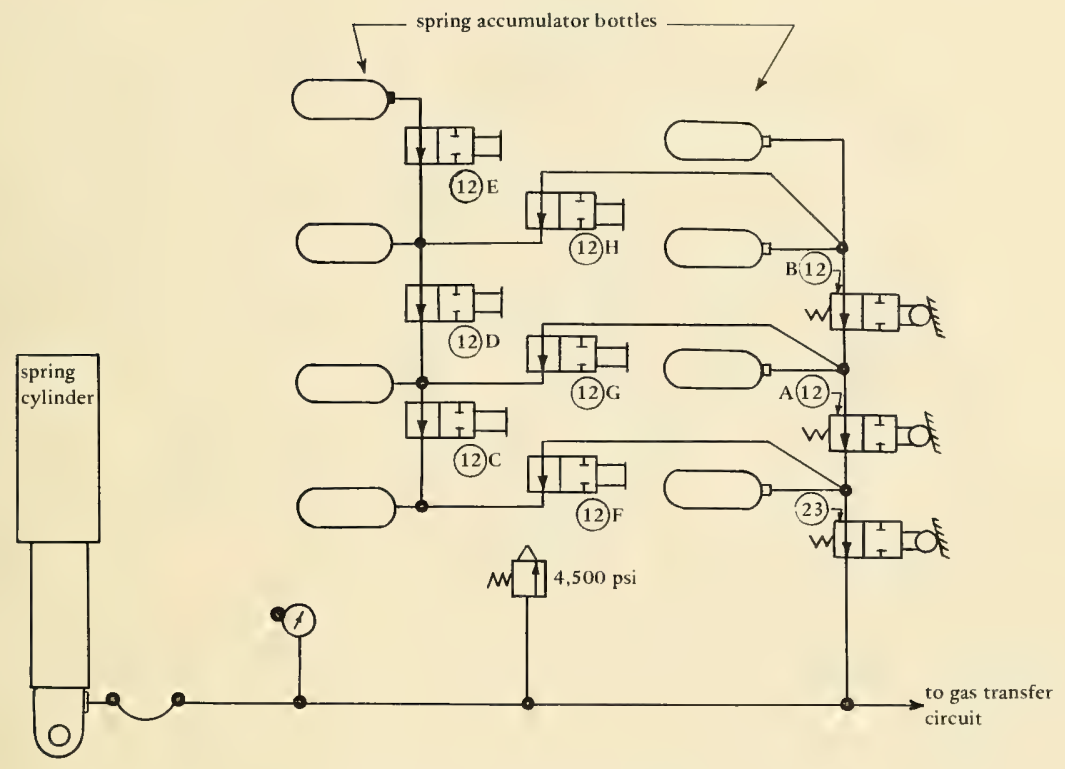

Figure 16. Spring system schematic.

Comparison of these resonant periods with the expected 2 to 12 -second range of ship-motion periods indicated that the system did not meet the design objective of a natural resonance period much greater than the ship-motion periods. A redesign of the spring system doubled the spring accumulator volume. When the system was retested with the large accumulator and the 63,250-pound boom-tip load, the resonant period was about 20 seconds, thus satisfactory for the ship motions of interest. System damping was near critical or possibly overdamped.

\section{Sea Tests}

All at-sea testing was conducted with the MCLS mounted on the fantail of the MV GEAR (ARS 34) (Figures 20 and 21). The at-sea test program consisted of two series of tests, the first in September and October of 1972 and the second during October and November 1973. Test instrumentation covered system performance topside and at the payload in both real time and recorded data. Details of the test instrumentation system are included as the Appendix.

Two different payloads were used during the testing program. The light payload (Figure 22) was selected to give an in-water weight near the 10,000 -pound minimum the MCLS was expected to be able to handle. The heavy payload (Figure 23) had an in-water weight of 40,000 pounds, the maximum design capability of the MCLS.

The planned test sequence throughout both test series was to launch the payload being used, shift into soft mode, lower it to depth, hold it at that depth for 15 minutes, lift it back to the surface, shift into hard mode, and recover. Planned test depths started at 1,000 feet and lowered incrementally to 6,000 feet. Additional holds were used at intermediate depths on the 1,000-foot tests to gain additional data. 
to connection B

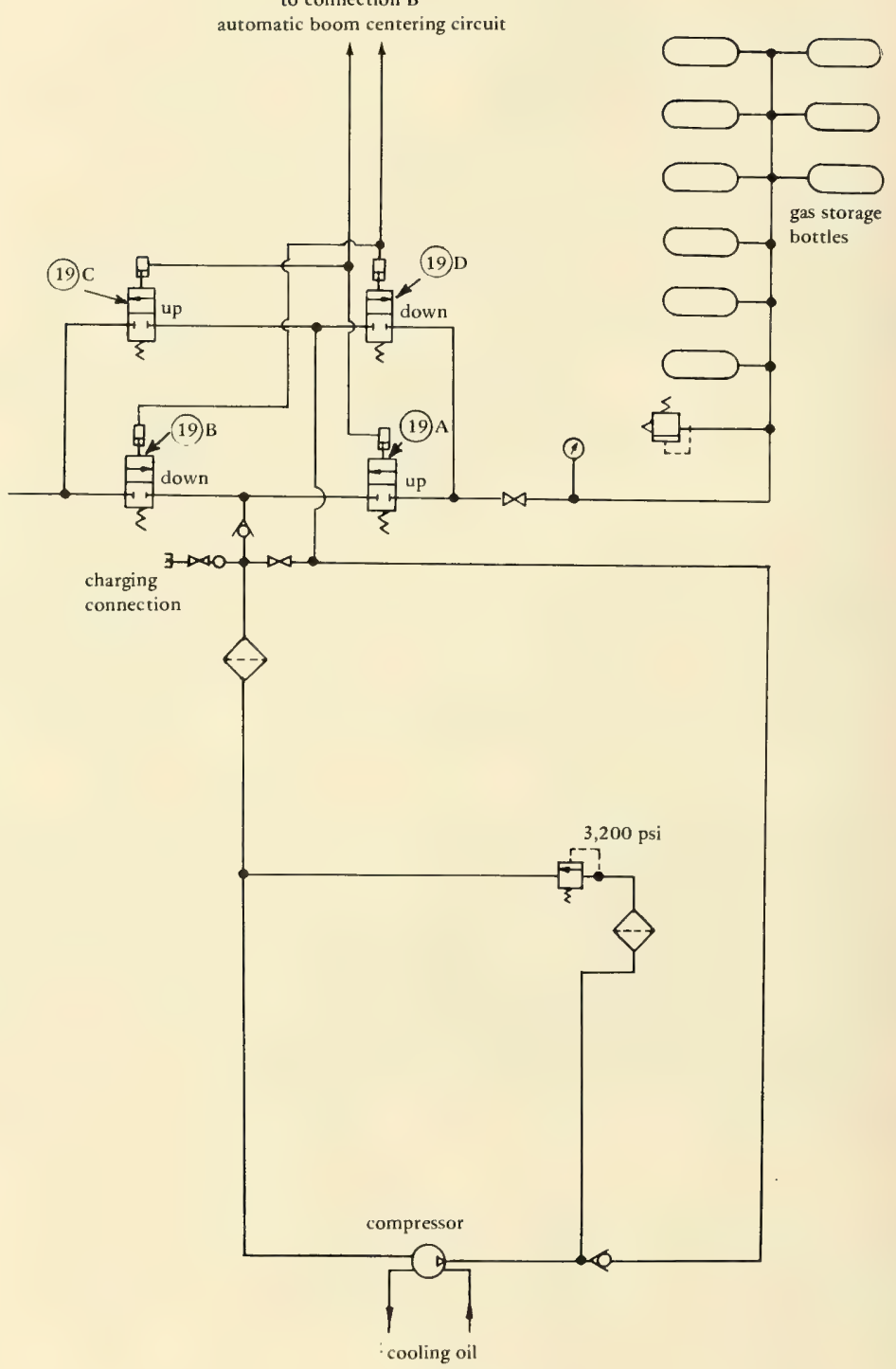

Figure 17. Gas-transfer circuit. 


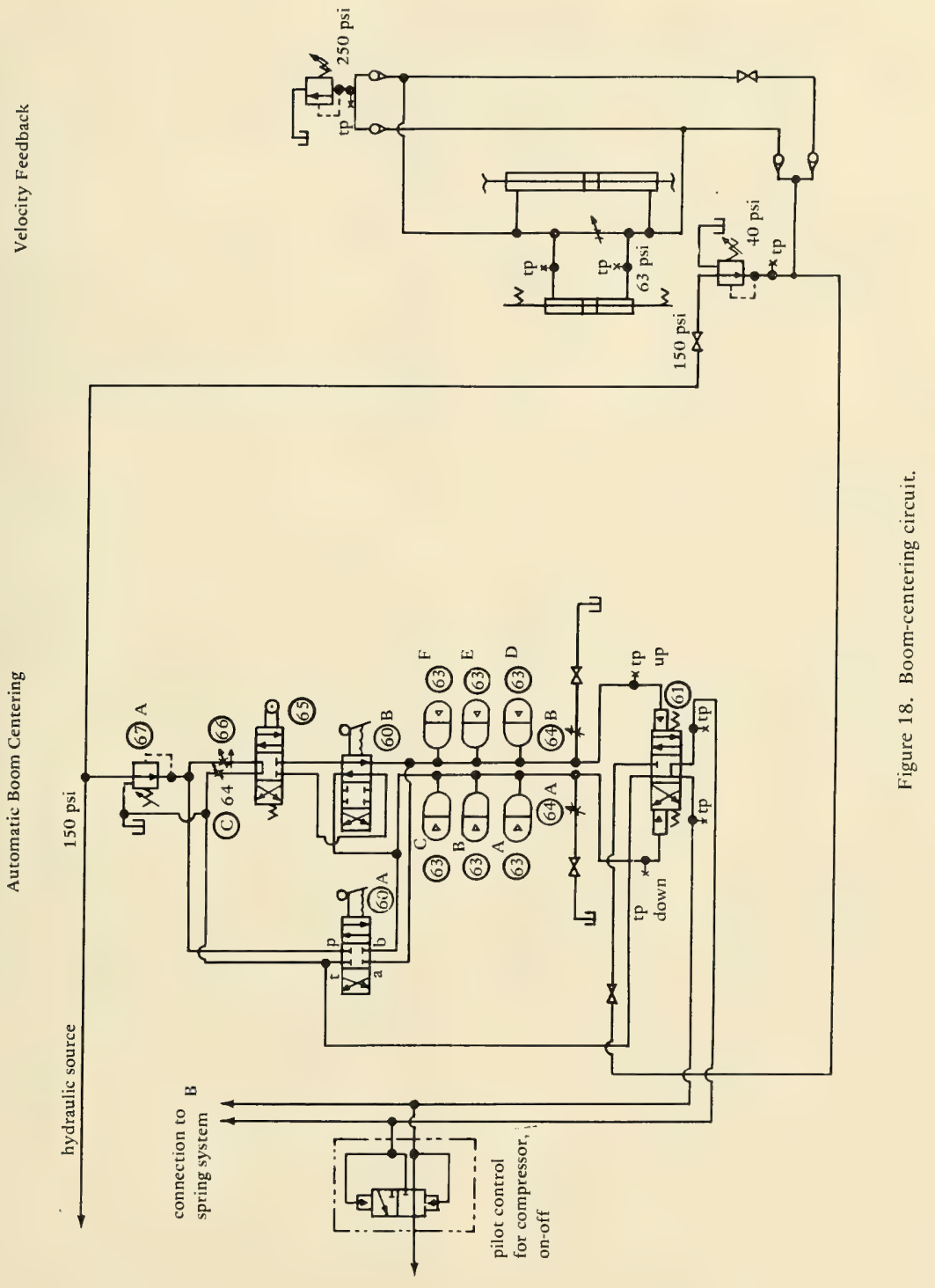


First Test Series, 1972. The first test series began on 28 September 1972 with two 1,000-foot tests using the light payload. Sea conditions for the entire 1972 test series were in the sea state 2 range, with waves rarely exceeding a peak-to-trough height of 3 feet and ship-motion response periods averaging between 5 and 6 seconds. This first test has a twofold purpose - to obtain operating data on the MCLS and also to fine-tune the automatic boom-centering system. Immediately upon launching of the payload and shifting into soft mode, problems were encountered with the boom hitting the stops at the end of its travel limits. After 2 or 3 minutes the boom moved away from the stops and, with a few exceptions, did not impact upon them again during this test. A "hunting" of the automatic boom-centering circuit was observed and later determined to have a period of about 200 seconds and an amplitude of about 4-1/2 feet. Upon successful completion of the first test, a second test was conducted the same day using the same payload. On this run no boom impacting of the stops was recorded, and the hunting behavior of the automatic boom-centering circuit was reduced. Apparently this was due to successful tuning by the contractor's technical representative who was on-board throughout the entire test sequence.

On 2 October, the heavy payload was used in the third test in this series and descended to the same 1,000 -foot depth as in tests 1 and 2. Problems with the boom impacting the stops were encountered immediately after payload launching and continued for 3 to 4 minutes during payout. Boom-stop impacting was also experienced for two or three short intervals later in the test. Hunting of the automatic boom-centering system was again evident. Later examination of the records for this test showed this hunting oscillation had a period of about 190 seconds and an amplitude at the boom tip of about 5 to 6 feet. About 4 minutes after lifting of the payload from the 1,000-foot depth commenced, problems occurred in the traction-winch system that were later determined to be due to a loss of oil from the reservoir, causing cavitation in the hydraulic pumps. The oil loss was due to failure of the main shaft seal of the traction-winch drive motor, allowing the oil to escape into the traction-winch gear box. Post-failure investigation by the contractor determined that the seal failure was due to a massive failure of the main structural housing of the drive motor. It was believed that the failure could have been due to some defect or weakness in the motor, possibly one inherent in the specific type used. As a result a redesign of the traction-winch system was undertaken and the MCLS modified accordingly. Other problems that had occurred during the 1972 tests were also examined and fixes incorporated into the MCLS at the same time.

Second Test Series, 1973. The second test series began on 6 October 1973 with the modified MCLS with a shallow (500-foot depth) test using the light payload. Sea conditions ranged from middle to high sea state 3 during this test. Numerous problems were encountered immediately after shifting into soft mode, including the almost continuous impacting of the boom on the stops combined with an apparent dynamic instability in the automatic boom-centering system. Because of the severity of the problems the test was terminated early and the ship returned to port where the MCLS control circuits were retuned. A 6-week delay in the test program then occurred with the departure of the $M V G E A R$ on a priority salvage call. Testing resumed on 19 November with a repeat of the test attempted on 6 October. The same problems were encountered again, and a major effort was unsuccessfully made to eliminate them by on-site tuning of the control circuits.

Indications at this point were that internal system friction had increased since the 1972 tests and was causing the control-system problems. It was decided to try again but with the heavy payload, on the theory that with the larger line tensions the frictional forces would be relatively smaller and thus have less effect on system performance. This test was conducted on 21 November, again at the shallow 500-foot site. Boom-impacting problems were again apparent immediately after shifting into soft mode, and further efforts were made to tune the control system. Approximately 10 minutes after launching, with the payload at a depth of 250 feet, a partial failure of the pneumatic spring cylinder seal occurred and the test was aborted. Almost immediately after starting to lift the payload, problems were encountered with the traction-winch drive system. Emergency payload recovery procedures were again used, and the payload was successfully lifted to a depth of about 60 feet - where the traction-winch drive system failed completely. The payload was then placed on the bottom and later recovered by another vessel. 


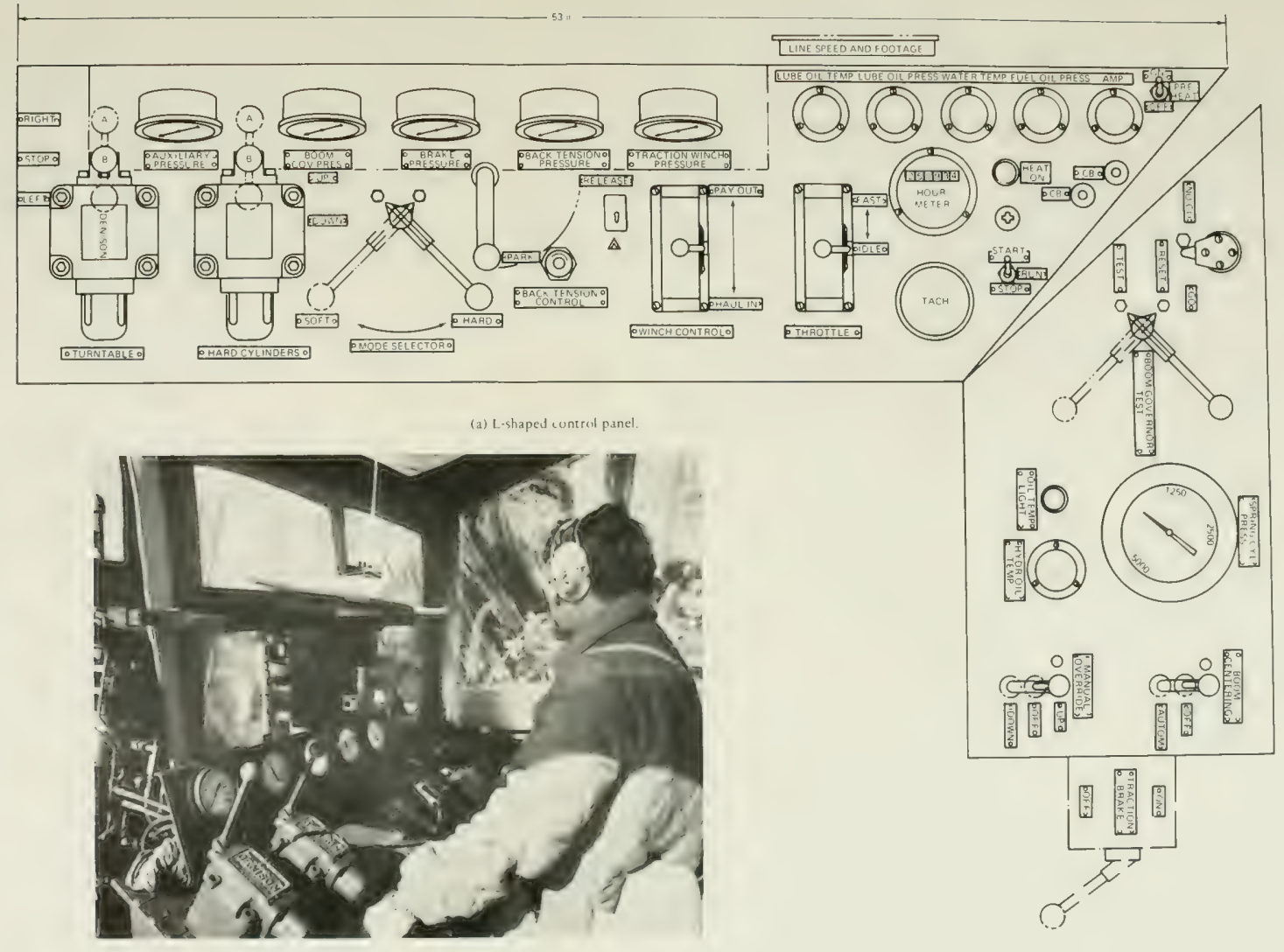

(b) MCLS operator at the control console. 



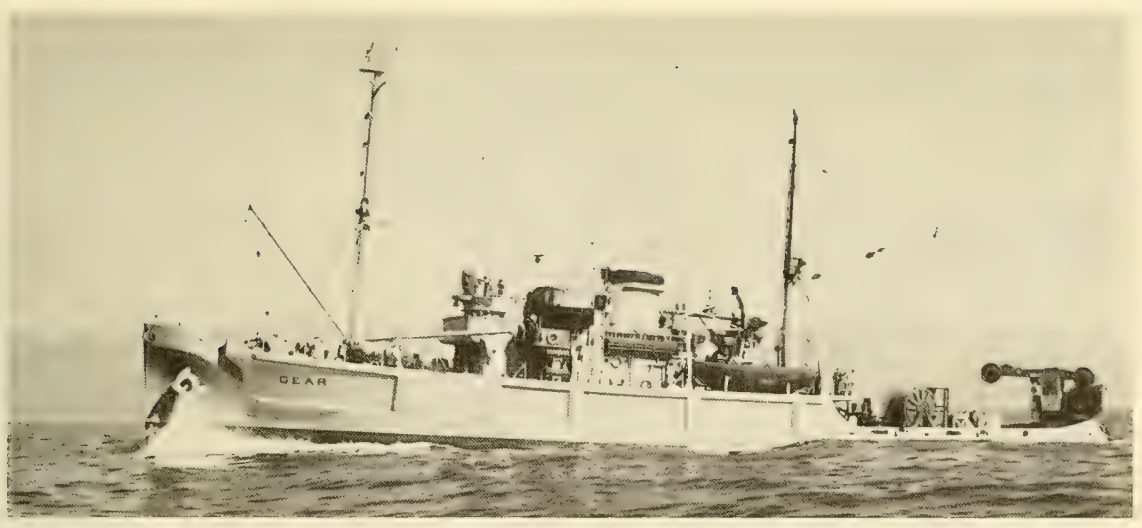

Figure 20. MV Gear.

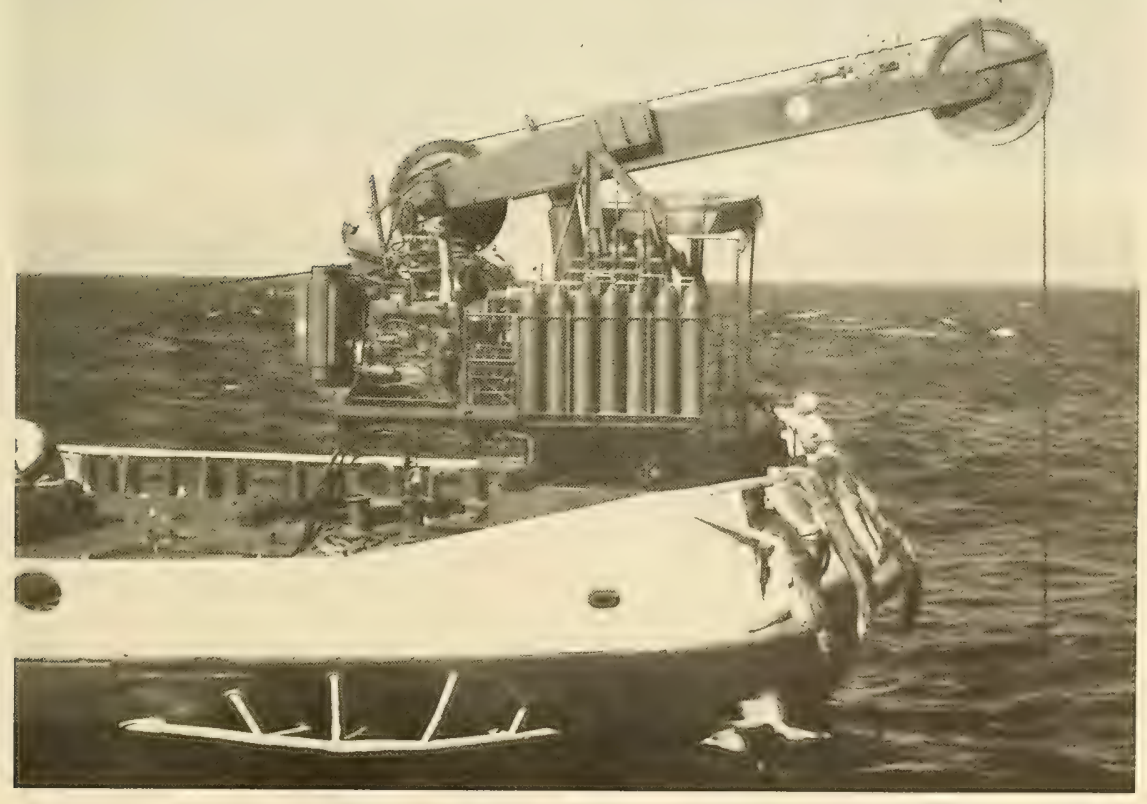

Figure 21. MCLS installed on $M V$ Gear. 

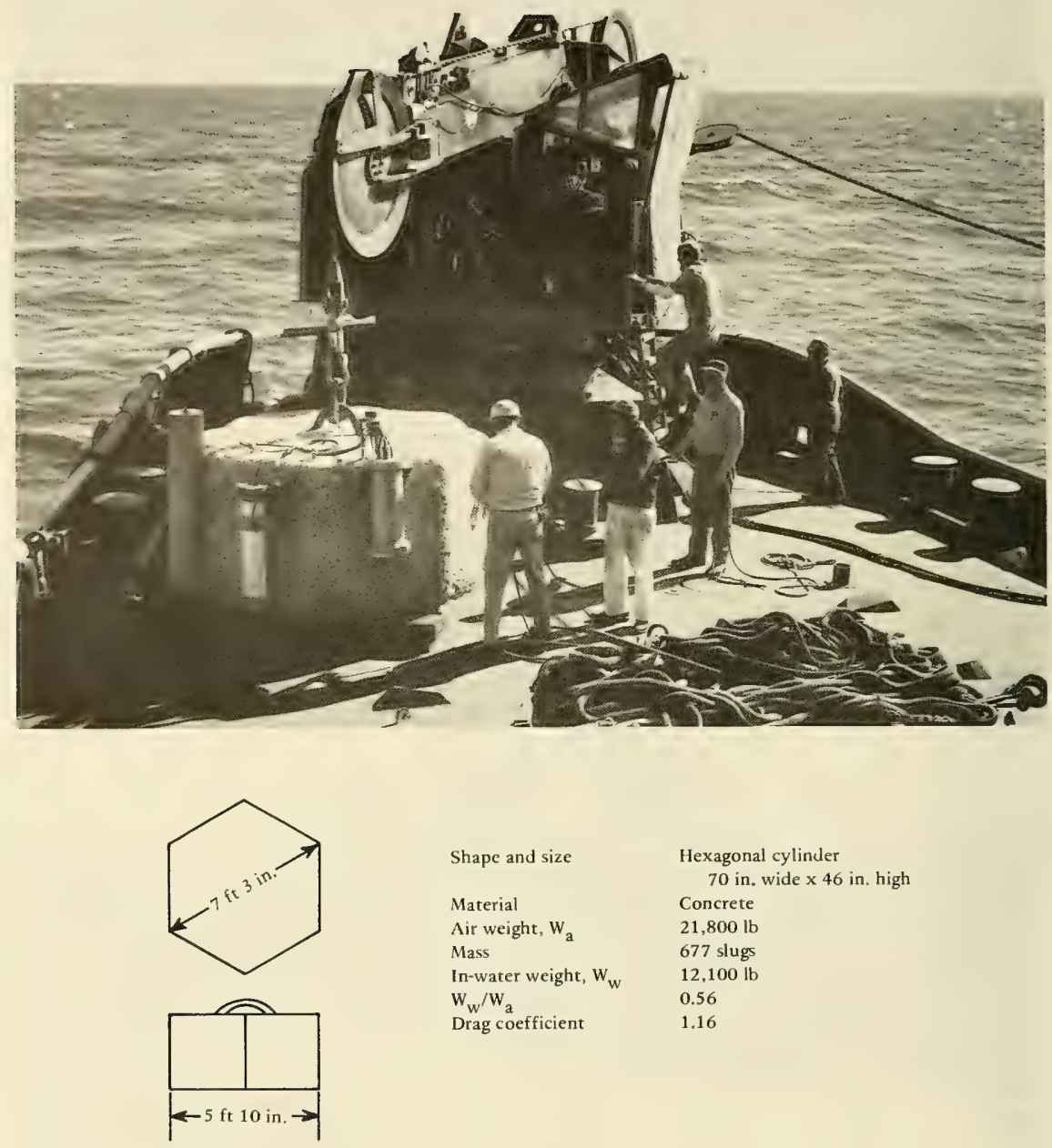

Shape and size

Material

Air weight, $\mathrm{w}_{\mathrm{a}}$

Mass

In-water weight, $\mathrm{W}_{\mathrm{w}}$

$\mathrm{w}_{\mathrm{w}} / \mathrm{w}_{\mathrm{a}}$

Drag coefficient
Hexagonal cylinder

70 in. wide $\times 46$ in. high

Concrete

$21,800 \mathrm{lb}$

677 slugs

$12,100 \mathrm{lb}$

0.56

1.16

Figure 22. Light test payload. 

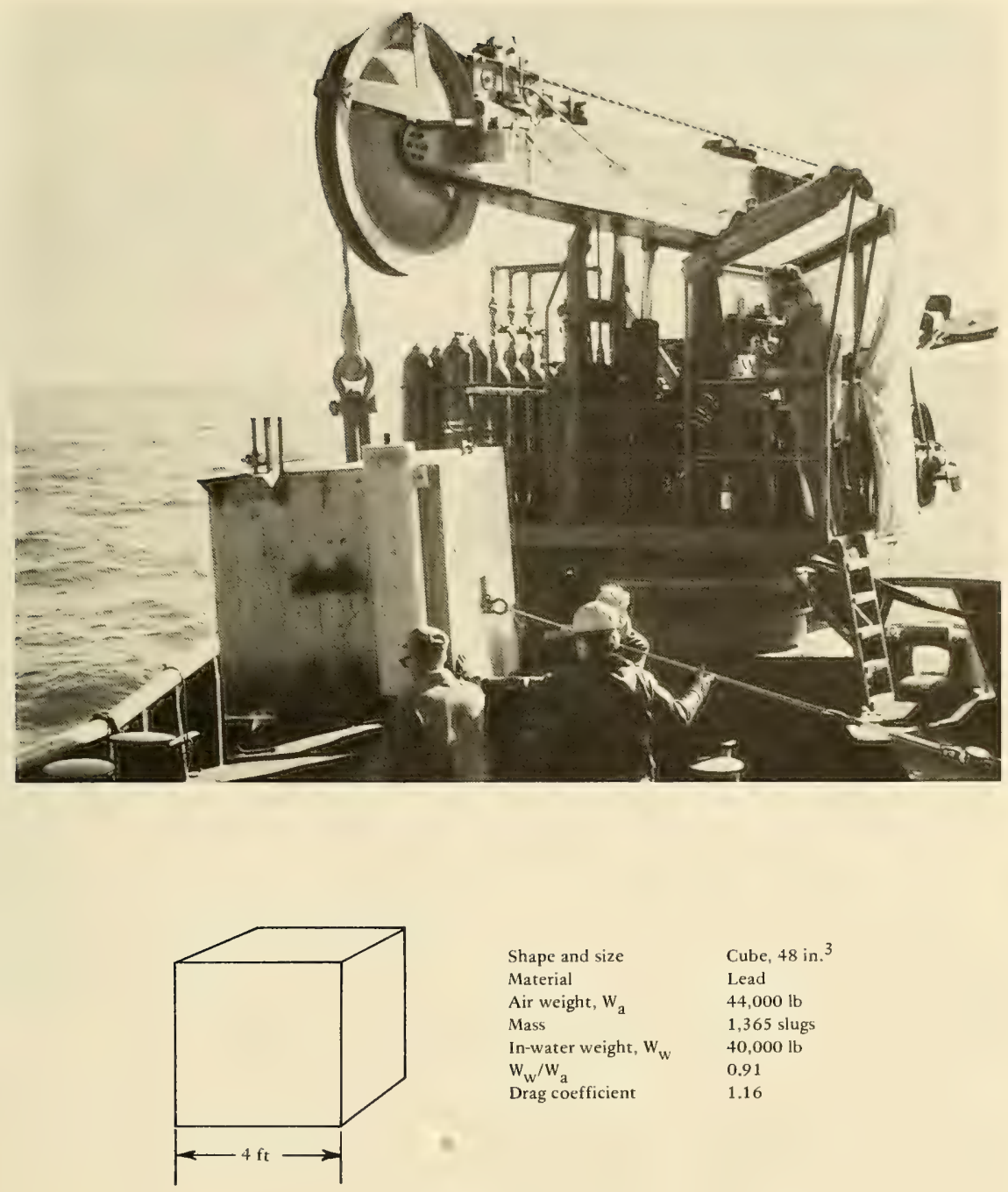

Shape and size

Material

Air weight, $w_{a}$

Mass

In-water weight, $\mathbf{w}_{\mathrm{w}}$

$w_{w} / w_{a}$

Drag coefficient
Cube, 48 in. $^{3}$

Lead

44,000 lb

1,365 slugs

$40,000 \mathrm{lb}$

0.91

1.16

Figure 23. Heavy test payload. 
The MCLS was again returned to the contractor. Although the evidence is not completely definitive, the most probable cause for the traction-winch drive failures in 1973, as well as in 1972, appears to be high-intensity impact loadings occurring when the boom hits the bottom stops and the payload is abruptly accelerated upward. This process creates very large dynamic-tension loads in the lift wire that are transmitted directly to the traction-winch drums. Because of the extremely short rise times associated with these tension pulses, the loading on the pinion gear, which drives both traction-winch drums, may not have been symmetrical. Nonsymmetrical forces on the pinion would, in turn, create large side loads on the pinion shaft and bearings, much larger than they were designed to withstand. In fact, examination of both drive systems does show massive failure of the pinion drive-shaft bearings and associated bearing retainers.

\section{TEST RESULTS}

In spite of the many problems encountered during the at-sea test series, useful data were obtained on the performance of the MCLS. The two basic parameters of interest are the dynamic tension control and the payload motion. Due to a variety of instrumentation difficulties, valid payload motion data were not obtained. Comparison of boom-tip and deck vertical-acceleration records indicates that some motion reduction was obtained, although the magnitude of the reduction could not be determined.

Valid dynamic tension data were obtained for all tests except the one conducted on 6 October 1973. Tension data are considered valid for intervals (data sets) in which no boom-impact-induced dynamic loading occurs. In most cases valid data in both hard and soft modes exist for each test so that the reduction in dynamic tensions attributable to the MCLS can be determined along with the dynamic/static tension ratios. For each test record examined, a series of data sets representative of the entire record were chosen; each set was a tension-time record of 30 to 60 -second duration. For each set, the envelope of peak dynamic tension variations was determined along with the mean, or static, tension. Table 2 , a summary of the dynamic tension data, shows that the dynamic-line tension was, on the average, controlled to less than $14 \%$ of the static value. This is a reduction of about 2 to 1 in dynamic-line tensions over the-noncompensated mode of operation.

\section{SUMMARY}

In considering the potential for motioncompensating lift systems of the passive, fluid-spring, boom-bobber type described in this report, it is necessary to differentiate between the limitations of the basic concept and the limitations of the specific hardware. It is believed that a boom-bobber system using a passive fluid spring is capable of providing the motion compensation and line-tension control to the degree specified in the original Request for Proposal (RFP). However, careful attention must be given in the designing process to the type of problems encountered with the existing MCLS hardware as described in this report.

In a review of the past series of tests, a number of problem areas that contributed directly to the system failures become evident. One of the most critical problems seemed to be the lack of understanding of the importance of the system's nonlinearities and the need for a comprehensive quantitative analysis of all proposed hardware prior to fabrication. Parameters such as the boom-spring geometry, variable gas "constant," internal "sticktion," internal damping due to fluid flow, and control-system characteristics must be included in the analysis. At the time of the present system's development it was felt by the contractor that a linear approximation would provide a valid representation of system performance. It is now apparent that only a comprehensive nonlinear computer model of the system, used with random ship-motion data for input, is adequate to provide realistic modeling of expected system performance.

Another questionable area was what happened when the boom tried to travel beyond its normal stroke limitations. Again, hindsight shows that some sort of progressive hardening, or cushioning, of the boom is required as it approaches either end of its stroke. This feature is mandatory to prevent the damaging impact loading experienced with the existing MCLS when the boom hit the stops. It is believed that any seagoing system such as the MCLS will, sooner or later, be pushed to or beyond its

* System breakaway friction. 
Table 2. Summary of Test Results

\begin{tabular}{|c|c|c|c|c|c|c|c|c|c|}
\hline \multirow{2}{*}{ Date } & \multirow{2}{*}{ Sea State } & \multirow{2}{*}{ Payload } & \multirow{2}{*}{ Mode } & \multirow{2}{*}{$\begin{array}{l}\text { Data } \\
\text { Sets }\end{array}$} & \multicolumn{3}{|c|}{$\begin{array}{l}\text { Dynamic Line Tension } \\
\text { (Percent of Static) }\end{array}$} & \multicolumn{2}{|c|}{ Ship-Motion Averages } \\
\hline & & & & & Average & Maximum & Minimum & Deck Acceleration $(\mathrm{g})$ & Period (sec) \\
\hline 28 Sep 1972 & 2 & $\operatorname{light}^{a}$ & $\begin{array}{l}\text { hard } \\
\text { soft }\end{array}$ & $\begin{array}{l}2 \\
4\end{array}$ & $\begin{array}{l}29.6 \\
13.1\end{array}$ & $\begin{array}{l}45.5 \\
15.4\end{array}$ & $\begin{array}{l}13.6 \\
10.7\end{array}$ & $\begin{array}{l}0.0071 \\
0.011^{b}\end{array}$ & $\begin{array}{l}4.96 \\
5.08^{b}\end{array}$ \\
\hline 28 Sep 1972 & 2 & light & $\begin{array}{l}\text { hard } \\
\text { soft }\end{array}$ & $\begin{array}{r}0 \\
11\end{array}$ & 10.9 & $\overline{-}$ & $\overline{8.9}$ & $0.0095^{c}$ & $5.47^{c}$ \\
\hline 2 Oct 1972 & 2 & heavy $^{d}$ & $\begin{array}{r}\text { hard } \\
\text { soft }\end{array}$ & $\begin{array}{r}6 \\
12\end{array}$ & $\begin{array}{l}20.0 \\
13.7\end{array}$ & $\begin{array}{l}27.4 \\
23.1\end{array}$ & $\begin{array}{r}11.1 \\
9.7\end{array}$ & $0.0095^{c}$ & $\begin{array}{l}5.9 \\
5.8\end{array}$ \\
\hline 19 Nov 1973 & 3 & light & $\begin{array}{r}\text { hard } \\
\text { soft }\end{array}$ & $\begin{array}{r}4 \\
11\end{array}$ & $\begin{array}{l}31.3 \\
13.2\end{array}$ & $\begin{array}{l}48.5 \\
18.6\end{array}$ & $\begin{array}{l}16.2 \\
10.5\end{array}$ & $\begin{array}{l}0.13^{C} \\
0.14\end{array}$ & $\begin{array}{l}5.0^{c} \\
4.5\end{array}$ \\
\hline 21 Nov 1973 & 3 & heavy & $\begin{array}{l}\text { hard } \\
\text { soft }\end{array}$ & $\begin{array}{l}5 \\
5\end{array}$ & $\begin{array}{l}22.4 \\
12.8\end{array}$ & $\begin{array}{l}33.6 \\
16.0\end{array}$ & $\begin{array}{r}13.0 \\
9.5\end{array}$ & $\begin{array}{l}0.16 \\
0.12\end{array}$ & $\begin{array}{l}5.1 \\
4.9\end{array}$ \\
\hline
\end{tabular}

$a_{12,100}$ pounds in water.

${ }^{b}$ Based on six data sets.

${ }^{c}$ Based on five data sets.

$d_{40,000}$ pounds in water.

design operation limits by an unavoidable combination of unexpected circumstances. An understanding of what can be expected when this happens is necessary to ensure the survivability of such a system.

In answer to the question of what changes need to be made in the existing hardware to make it perform satisfactorily, the first step is to conduct a comprehensive nonlinear analysis.

This analysis, combined with measurements of gas temperatures and pressures on the existing hardware, can then be used to provide specific quantitative requirements for the following items.

1. Modification of the spring system to provide an adequate cushion at each end of the boom stroke to ensure survivability.

2. Increase in the amount of the boomstroke to allow for the less-than-perfect accuracy in the automatic boom-centering system.
3. Improvement in the automatic boomcentering system.

4. Reduction of the internal sticktion of the system.

\section{CONCLUSIONS AND RECOMMENDATIONS}

Based on the totality of the development and the testing effort with the existing MCLS hardware, the following conclusions and recommendations are presented:

1. A passive, fluid-spring lift system of the boombobber type can be designed and built to provide significant motion-compensating capabilities for single-cable lifts in sea conditions at least through sea state 3 . 
2. Successful design of any such system is dependent on the use of comprehensive nonlinear modeling of the proposed system throughout the design phase to determine expected performance over the entire range of planned operating conditions.

3. A boom-bobber system properly designed causes essentially no fatigue of the lift cable compared to most other systems and, thus, should receive careful consideration for all applications where lift-line fatigue life is a major concern.
4. The pure pneumatic spring used in the existing MCLS is less desirable than a hydraulic cylinder combined with a series of oil-over-gas accumulators because of the difficulty of achieving the desired pneumatic spring rate characteristic.

5. A boom-bobber system appears to offer significant dynamic line-tension control for all single-cable lift requirements where the effective spring constant of the lift cable selected is relatively high (e.g., wire rope, Kevlar rope, and short lengths of nylon and other synthetic lines). 


\section{Appendix}

\section{TEST INSTRUMENTATION SYSTEM}

The test instrumentation system described below was based on commercial equipment when available. Certain specialized items, including the payload-mounted fathometer and rotation counter units and the acoustic data-transmission system, were built by CEL. Power for the topside instrumentation
(Figure 24) was 110 VAC supplied by the support ship. Payload-mounted instrumentation (Figure 25) was powered by a nickel-cadmium battery pack in a sealed pressure housing. Figure 26 with the component list describes the functioning of the instrumentation. 


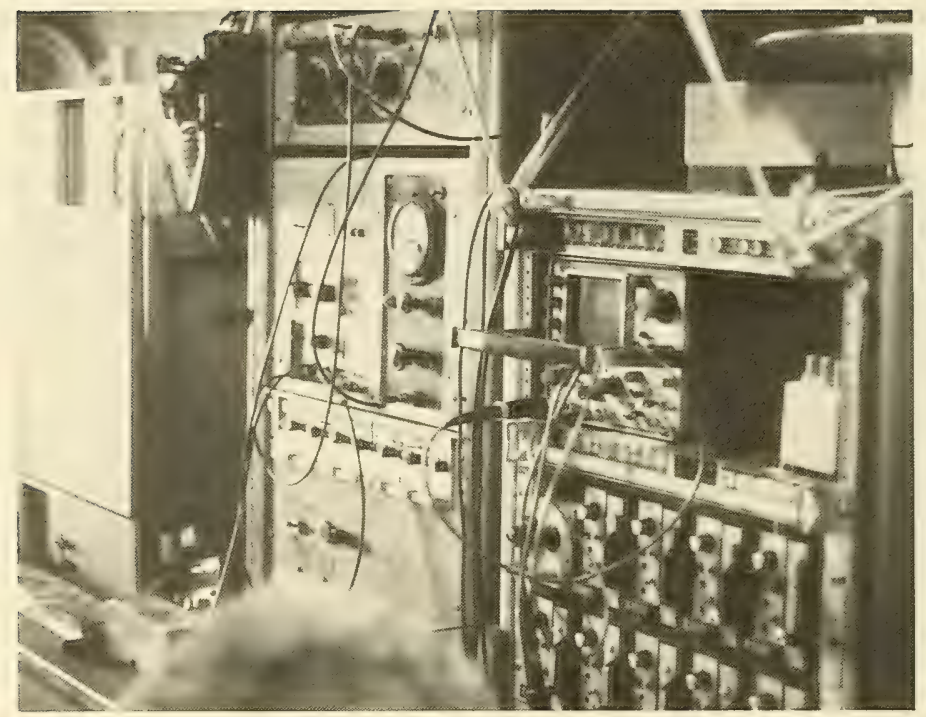

Figure 24. Shipboard instrumentation.

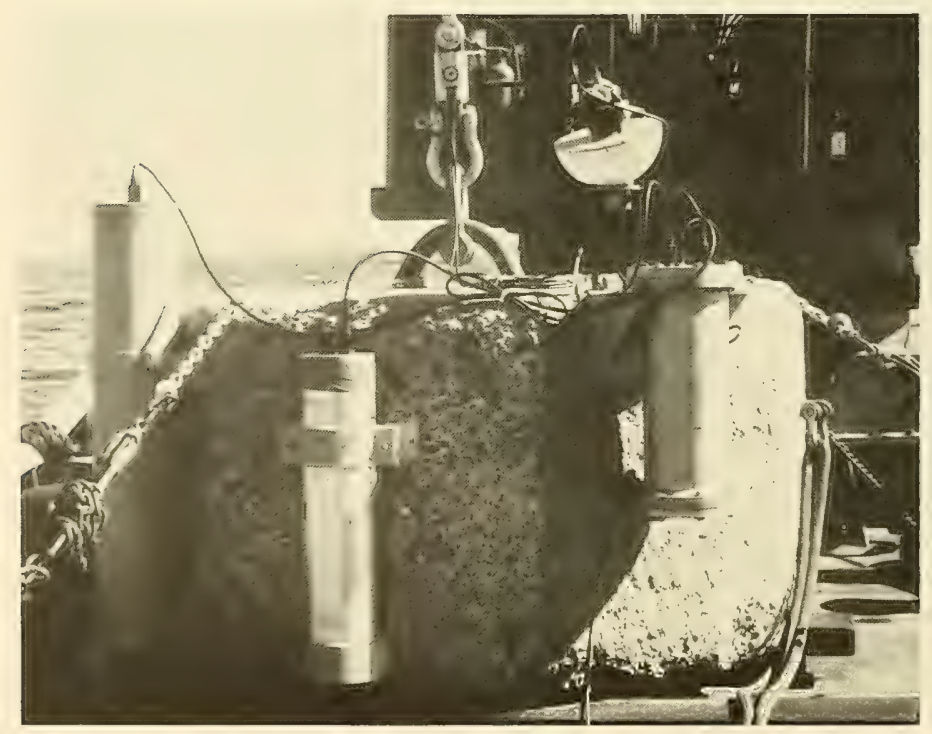

Figure 25. Payload-mounted instrumentation. 

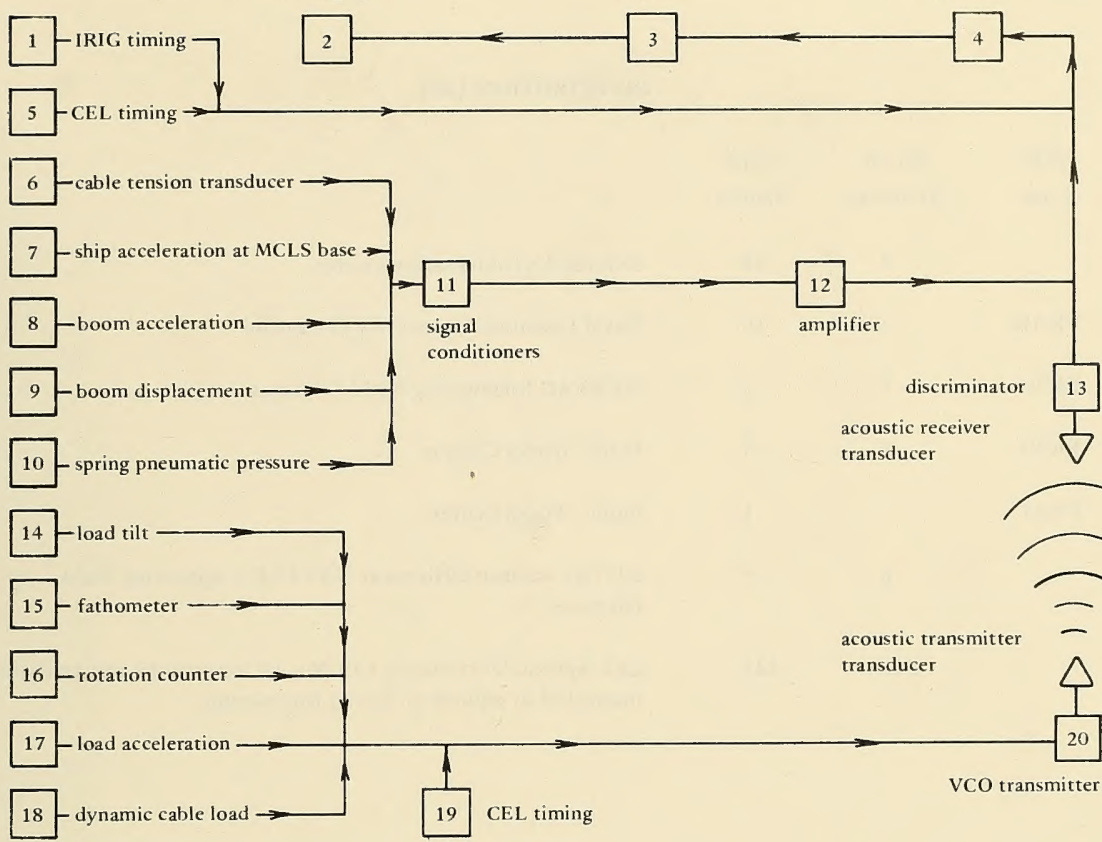
transducer

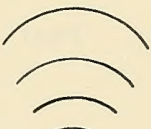
transducer

coustic transmitter

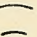

\begin{tabular}{|c|c|c|c|c|c|}
\hline No. & Instrumentation & Description & No. & Instrumentation & Description \\
\hline 1 & $\begin{array}{l}\text { Interrange Instrumentation } \\
\text { Group (IRIG) Timing }\end{array}$ & data reduction & 11 & Signal Conditioning Unit & $\begin{array}{l}\text { balancing, calibration, } \\
\text { and bridge excitation }\end{array}$ \\
\hline 2 & Oscillograph & $\begin{array}{l}\text { frequency response } \\
\text { to } 5 \mathrm{kHz}\end{array}$ & 12 & Amplifier & $\begin{array}{l}\text { frequency response to } \\
20 \mathrm{kHz} \text {, DC }\end{array}$ \\
\hline 3 & Amplifier & $\begin{array}{l}\text { frequency response } \\
\text { to } 20 \mathrm{kHz}\end{array}$ & 13 & Discriminators & $\begin{array}{l}\text { frequency response to } \\
30 \mathrm{~Hz}\end{array}$ \\
\hline 4 & Tape Recorder & $\begin{array}{l}\text { frequency response } \\
\text { to } 20 \mathrm{kHz}\end{array}$ & 14 & $\begin{array}{l}\text { Single-Axis Load-Tilt } \\
\text { Indicator }\end{array}$ & 0 to 90 degrees $\pm 2 \%$ \\
\hline 5 & CEL Timing Network & $\begin{array}{l}\text { synchronous timing } \\
\text { frequency of } 1 \mathrm{~Hz} \\
\pm 1 \mathrm{ppm} / \mathrm{hr}\end{array}$ & 15 & Fathometer & $\begin{array}{l}\text { distance from load to } \\
\text { bottom, } 25 \text { to } 200 \\
\text { feet off bottom, } \pm 1 \%\end{array}$ \\
\hline 6 & Load cell & $\begin{array}{l}75,000 \mathrm{lb} \text {, response } \\
\text { time }<1 \mathrm{msec}\end{array}$ & 16 & Rotation Counter & on load \\
\hline 7 & Accelerometer & $\begin{array}{l}0.05 \mathrm{~g} \text { to } 0.5 \mathrm{~g} \pm 1 \% \\
\text { resolution } 0.1 \%\end{array}$ & 17 & Accelerometer & $\begin{array}{l}0.05 \text { to } 0.25 \mathrm{~g} \pm 0.05 \% \text {, } \\
\text { resolution } 0.0005 \%\end{array}$ \\
\hline 8 & Accelerometer & $\begin{array}{l}0.05 \mathrm{~g} \text { to } 1.5 \mathrm{~g} \pm 1 \% \\
\text { resolution } 0.1 \%\end{array}$ & 18 & Load cell & $\begin{array}{l}75,000 \mathrm{lb} \text {, response } \\
\text { time }<1 \mathrm{msec}\end{array}$ \\
\hline 9 & Boom- Tip Displacement & $\begin{array}{l}\text { relative to ship } \pm 9 \\
\text { feet } 3 \% \text { of full- } \\
\text { scale accuracy }\end{array}$ & 19 & Timing Network & $\begin{array}{l}\text { correlation timing, } \\
\text { frequency of } 1 \mathrm{~Hz} \\
\pm 1 \mathrm{ppm} / \mathrm{hr}\end{array}$ \\
\hline 10 & Pressure Transducer & $\begin{array}{l}0 \text { to } 3,500 \text { psi } \\
\pm 2 \% \text { (calibration } \\
\text { in } 50 \text {-psi increments) }\end{array}$ & 20 & VCO Transmitter & $\begin{array}{l}\text { bandwidth from } 25 \text { to } \\
35 \mathrm{~Hz}, 40-\mathrm{kHz} \text { carrier, } \\
1,700-\text { to } 2,300-\mathrm{Hz} \\
\text { subcarrier }\end{array}$ \\
\hline
\end{tabular}

Figure 26. Flow chart for instrumentation system. 
DISTRIBUTION LIST

$\begin{array}{cccc}\begin{array}{l}\text { SNDL } \\ \text { Code }\end{array} & \begin{array}{c}\text { No. of } \\ \text { Activities }\end{array} & \begin{array}{c}\text { Total } \\ \text { Copies }\end{array} & \\ \text { FKAIC } & 1 & 12 & \begin{array}{l}\text { Defense Documentation Center } \\ \text { FKNI }\end{array} \\ \text { FKN5 } & 6 & 10 & \text { Naval Facilities Engincering Command } \\ \text { FA25 } & 9 & 9 & \text { NAVFAC Engineering Field Divisions } \\ - & 1 & 1 & \begin{array}{l}\text { Public Works Center } \\ \text { RDT\&E Liaison Officers at NAVFAC Engineering Field } \\ \text { Divisions }\end{array} \\ & 6 & 6 & \begin{array}{l}\text { CEL Special Distribution List No. 11 for persons and activities } \\ \text { interested in reports on Ocean Engineering }\end{array}\end{array}$


